\title{
The biology and clinical potential of circulating tumor cells
}

\author{
Taja Lozar ${ }^{1}$, Klara Gersak ${ }^{1,2,3}$, Maja Cemazar²,4, Cvetka Grasic Kuhar², Tanja Jesenko² \\ ${ }^{1}$ Faculty of Medicine, University of Ljubljana, Ljubljana, Slovenia \\ 2 Institute of Oncology Ljubljana, Ljubljana, Slovenia \\ ${ }^{3}$ General Hospital Izola, Izola, Slovenia \\ ${ }^{4}$ Faculty of Health Sciences, University of Primorska, Izola, Slovenia
}

Radiol Oncol 2019; 53(2): 131-147.

Received 23 March 2019

Accepted 3 May 2019

Correspondence to: Tanja Jesenko, Ph.D., Institute of Oncology Ljubljana, Department of Experimental Oncology, Zaloška 2, SI-1000 Ljubljana, Slovenia. Phone: +386 15879 545; E-mail: tjesenko@onko-i.si

Disclosure: No potential conflicts of interest were disclosed.

Background. Tumor cells can shed from the tumor, enter the circulation and travel to distant organs, where they can seed metastases. These cells are called circulating tumor cells (CTCS). The ability of CTCs to populate distant tissues and organs has led us to believe they are the primary cause of cancer metastasis. The biological properties and interaction of CTCs with other cell types during intravasation, circulation in the bloodstream, extravasation and colonization are multifaceted and include changes of CTC phenotypes that are regulated by many signaling molecules, including cytokines and chemokines. Considering a sample is readily accessible by a simple blood draw, monitoring CTC levels in the blood has exceptional implications in oncology field. A method called the liquid biopsy allows the extraction of not only CTC, but also CTC products, such as cell free DNA (cfDNA), cell free RNA (cfRNA), microRNA (miRNA) and exosomes.

Conclusions. The clinical utility of CTCs and their products is increasing with advances in liquid biopsy technology. Clinical applications of liquid biopsy to detect CTCs and their products are numerous and could be used for screening of the presence of the cancer in the general population, as well as for prognostic and predictive biomarkers in cancer patients. With the development of better CTC isolation technologies and clinical testing in large prospective trials, increasing clinical utility of CTCs can be expected. The understanding of their biology and interactions with other cell types, particularly with those of the immune system and the rise of immunotherapy also hold great promise for novel therapeutic possibilities.

Key words: circulating tumor cells; CTC; metastasis; liquid biopsy; cancer; disseminated tumor cells.

\section{Introduction}

The pathologist Thomas Ashworth first described tumor cells found in the circulation of a deceased patient in 1869. By comparing these cells to cells extracted from the patient's various malignant masses he considered a mutual origin of cancer in the patient. ${ }^{1}$ We now know tumor cells can shed from the tumor and enter the circulation and travel to distant organs, where they can seed metastases. These cells are called circulating tumor cells (CTCs). CTCs can also enter the bone marrow and stay in a dormant state for different length of time.
These cells are called disseminated tumor cells (DTCs). ${ }^{2}$ The ability of CTCs to populate distant tissues and organs has led us to believe they are the primary cause of cancer metastasis. Considering a sample is readily accessible by a simple blood draw, monitoring CTC levels in the blood has exceptional implications for the treatment of cancer patients. However, due to small numbers and short half-life of CTCs in the blood, the detection and identification remains a big diagnostic challenge. Additionally, CTCs experience constant genotypic and phenotypic changes, which make their identification even more challenging. Understanding 
CTC biology, tumor heterogeneity and metastatic spread on the one hand and improvement of detection methods and evaluation of prognostic and predictive value of CTCs on the other hand are one of the main objectives of cancer research as demonstrated by the enormous amounts of published literature in the recent years.

\section{CTC biology}

CTCs represent an intermediate step of the metastatic cascade. A tumor cell first leaves the primary or metastatic tumor site, invades into a blood or lymphatic vessel and circulates in the bloodstream before successfully forming a new tumor at a distant organ site. As determined in rat tumor model, millions of tumor cells break out of the primary tumor each day. ${ }^{3}$ However, the clearance of CTCs from the blood is fast as only a few of them can survive in the bloodstream due to a combination of physical stress (shear forces), anoikis (a form of cell death that occurs in anchorage-dependent cells when they detach from the surrounding extracellular matrix), immune surveillance and the lack of growth factors. The number of CTCs in the bloodstream is extremely small ( 1 to 10 cells per $10 \mathrm{ml}$ of blood). They can be found in the form of individual cells or cell clusters. ${ }^{4}$ Aceto et al. have demonstrated that breast cancer CTC clusters arise from oligoclonal tumor cell groupings held together through plakoglobin-dependent intercellular adhesions and not from intravascular aggregation of tumor cells. ${ }^{5}$ Similar polyclonal collective dissemination of keratin 14-expressing tumor cell clusters was observed in breast cancer mouse tumor model. ${ }^{6}$ It has also been demonstrated that cell clusters have 23 to 50 -fold increased metastatic potential compared to individual CTCs, which could be mediated through increased viability of cancer cells within a cluster. ${ }^{5} \mathrm{CTC}$ clusters can extravasate faster, therefore they have a shorter half-life in the circulation as individual CTCs (6-10 min for clusters vs. 25-30 min for single cells) that also aids in their survival and outgrowth. ${ }^{5}$ Due to emerging evidence on the importance of CTC clusters in metastatic cascade, molecular mechanisms of cell cluster formation and migration are being investigated. The study of Giampiery et. al. demonstrated that transforming growth factor beta (TGF $\beta$ ) signaling is involved in determination of the motile state of breast cancer cells. ${ }^{7}$ Two distinct modes of motility were observed: collective and as single cells. TGF $\beta 1$ switched cells from collective to single cell motility through a transcriptional program involving a Smad family co-mediator protein (Smad4), epidermal growth factor receptor (EGFR), neural precursor cell expressed developmentally downregulated protein 9 (Nedd9), myosin phosphatase Rho-interacting protein (M-RIP) and Ras homolog gene family, member $C$ (RhoC). When TGF $\beta$ signaling was blocked, only collective migration was observed. ${ }^{7}$ These finding are important in the scope of targeted therapy, as signaling pathways that contribute to the formation and migration of CTC clusters could be targeted.

\section{Epithelial-mesenchymal plasticity of CTCS}

In the early stages of the metastatic cascade, epithelial cells loose their apical-basal orientation, cell-tocell junctions and cell-to-matrix interactions, gaining the ability to separate from the primary tumor in the process of epithelial-mesenchymal transition (EMT), which is a fundamental physiological phenomenon that occurs during embryogenesis and wound healing. ${ }^{8}$ Factors that trigger EMT can be extracellular factors such as TGF $\beta$, epidermal growth factor (EGF), hepatocyte growth factor (HGF), insulin-like growth factor (IGF), fibroblast growth factor (FGF), Notch and homologous wingless (wg) and Int-1 (Wnt) protein family and others, as well as mechanical factors such as extracellular matrix density. ${ }^{9,10}$ These extracellular factors usually activate the transcription factors Twist family BHLH transcription factor 1 (TWIST1), Zinc finger protein SNAI1 (SNAIL), Zinc finger e-box binding homeobox 1 (ZEB1), Zinc finger e-box-binding homeobox 2 (ZEB2) (SIP1) and others. ${ }^{11}$ During EMT, the cell loses its epithelial markers (such as E-cadherin, epithelial cell adhesion molecule (EpCAM), cytokeratins and others) and obtains mesenchymal markers (such as vimetin and $\mathrm{N}$-cadherin). The newly obtained mesenchymal phenotype allows the cells to migrate and invade through the basement membrane into the blood vessels. After intravasation, cells circulate in the bloodstream as CTCs, until they exit the vessel at a distant site to seed micro metastases. In order to successfully seed and form a secondary tumor, the cells must regain their epithelial phenotype, hence they undergo a reverse process of EMT - mesenchymalepithelial transition (MET). ${ }^{12}$ EMT and MET thus enable tumor cells of epithelial origin to disseminate and colonize distant organs. Therefore, CTCs show high level of epithelial-mesenchymal plastic- 


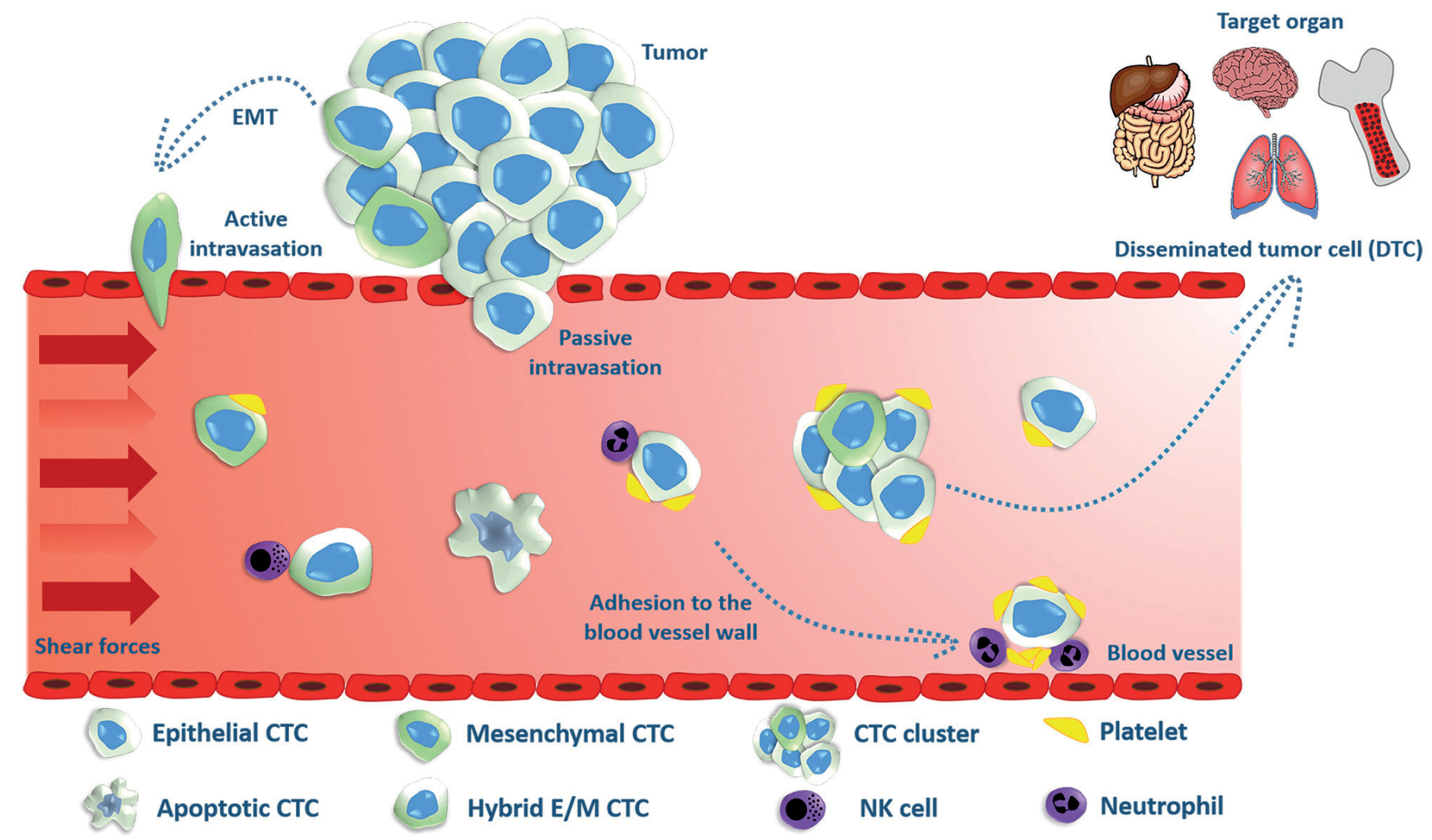

FIGURE 1. Circulating tumor cells (CTCS) can enter the blood vessel via active intravasation involving epithelial-mesenchymal transition (EMT) or by passive shedding due to compromised tumor vasculature. CTCs can exist in different phenotypes- epithelial, mesenchymal or both- hybrid epithelial/ mesenchymal phenotype (hybrid E/M). CTCs can be found in the form of individual cells or cell clusters; the latter show increased metastatic potential compared to individual CTCs. Platelet-CTC interaction in the blood vessel acts as a shield against the shear stress of blood flow, immune attack and also enables the adhesion to the blood vessel wall and extravasation. After the arrest of CTCs in the bone marrow or distant organ, they can extravasate and remain in the target tissue in the form of disseminated tumor cell (DTC).

ity and can be isolated from peripheral blood in different phenotypes-epithelial, mesenchymal or both- hybrid epithelial/mesenchymal phenotype (hybrid E/M), also referred to as partial, intermediate or incomplete EMT phenotype (Figure 1). ${ }^{13-15}$ Cells in hybrid E/M phenotype have mixed epithelial (e.g., adhesion) and mesenchymal (e.g., migration and invasion) properties that enable collective migration and invasion in the form of cell clusters. Therefore, hybrid E/M cell clusters seem to have the highest metastatic potential of all CTC variants. ${ }^{5}$ Furthermore, they also exhibit stemness; i.e. tumor-initiating properties. ${ }^{16,17}$

\section{CTCs in the circulation}

Tumor cells can enter the circulation through a blood or lymphatic vessel, depending on a number of factors including their accessibility, physical restrictions and active mechanisms for attracting cells to specific types of vasculature. ${ }^{18}$ Lymphatic intravasation is also a pathway by which tumor cells can enter the blood vessels, since lymph vessels eventually drain into the blood in the major thoracic duct. ${ }^{18}$ However, there is little evidence that lymphatic vessels do indeed enable further passage of significant numbers of cancer cells to the bloodstream, which indicates lymph vessel deposits are probably simply dead ends for cancer cells and may reveal the extent of parallel, concomitant dissemination from the primary tumor. ${ }^{19} \mathrm{On}$ the other hand, direct hematogenous transport is likely the main route of distant metastatic colonization. Along the way, lymphatic fluid is filtered through a series of lymph nodes, which are often the first sites of metastasis. Intravasation into a blood vessel can be an active or passive event, which depends on the tumor type, tumor microenvironment and blood vessel integrity. Active intravasation includes the invasion of tumor cells or cell clusters with increased migratory potential ac- 
quired through EMT into the blood vessel, whereas individual cells or cell clusters can also be shed passively into the blood stream due to compromised tumor vasculature (Figure 1). ${ }^{20}$ Once in the circulation, CTCs are exposed to the shear stress of blood flow, which together with anoikis and immune surveillance may be enough to destroy a large proportion of CTCs entering into the bloodstream. ${ }^{21} \mathrm{It}$ has also been demonstrated that CTCs in the blood stream have a short half-life; in patients with localized prostate cancer who had detectable CTCs, most of them no longer have evident CTCs at 24 hours following surgical resection of the primary tumor. ${ }^{22}$ However, some of the CTCs are capable of surviving the journey through circulation and forming distant metastasis. There is increasing evidence that interaction of CTCs with other blood components is crucial for their survival and metastatic potential. The most studied is indeed the interaction of CTCs with platelets. ${ }^{23}$ Platelet-CTC interactions may occur soon after the entry of CTCs into the circulation. One of the first interactions is the formation of platelet-rich thrombi around tumor cells, which is triggered by the platelet tissue factor (factor III/CD142) expressed by the tumor cells. ${ }^{24}$ This interaction acts as a shield against the shear stress of blood flow, immune attack and also enables the adhesion to the blood vessel wall and extravasation (Figure 1). ${ }^{24-26}$ It has been demonstrated that activated platelets can transfer the major histocompatibility complex (MHC) to CTCs, which enables the CTCs to mimic host cells and escape from immune surveillance. ${ }^{27}$ Furthermore, platelets can prevent tumor cell recognition and lysis by natural killer cells (NK cells). ${ }^{28}$ It has also been demonstrated that platelets can promote EMT of tumor cells within the circulation via the release of TGF $\beta$, also enhancing metastatic potential of CTCs. ${ }^{29}$ CTCs may also interact with various types of leucocytes; neutrophils, monocytes and macrophages, which could promote CTC survival and promote the interaction of CTCs with endothelial cells and extravasation. ${ }^{19}$

\section{Interaction of CTCs with immune cells in the bloodstream}

In tumor progression, tumors eventually go through the immunoediting process, which enables the tumor to establish an immunosuppressive microenvironment and escape from the immune surveillance. ${ }^{30}$ In the escape phase, tumor cells evade immune recognition through different mechanisms, including immune suppression mediated by immunosuppressive cells (regulatory $\mathrm{T}$ cells - Tregs) and myeloid-derived suppressor cells (MDSCs), reduction of immune recognition by down-regulation of antigen processing machinery affecting the major histocompatibility complex (MHC) I pathway, release of immune suppressive mediators (cytokines such as TGF $\beta$, vascular endothelial growth factor [VEGF] and expression of immunoregulatory molecules such as indoleamine-pyrrole 2,3-dioxygenase [IDO], programmed cell death protein 1 [PD-1] / programmed death ligand 1 [PD-L1], $\mathrm{T}$ cell Ig domain and mucin domain 3 [Tim-3] / galectin-9, lymphocyte-activation gene 3 [LAG-3]). ${ }^{30,31}$ Once the tumor cell leaves the immunosuppressive microenvironment of the primary tumor and enters the bloodstream, it interacts with several different types of immune cells, which can destroy the CTC in the bloodstream before its extravasation at distant site. On the other hand, interaction of tumors cells with immune cells can also promote tumor progression with the generation of hospitable microenvironment for metastatic growth ${ }^{32,33}$ or by maintaining CTC viability in the bloodstream and facilitating extravasation. ${ }^{23,34}$ Therefore, immune cells can hinder or favor the dissemination of CTCs.

CTCs interact with the components of the innate immune system in different ways. Natural killer cells (NK cells) in the bloodstream can intercept CTCs and destroy them before extravasation, thus preventing metastasis (Figure 1). Preclinical studies have shown that hosts with high NK cell activity (adult mice) are very resistant to metastasis compared to hosts with low NK cell activity (young mice) $)^{35}$ and that direct perforin-dependent killing by NK cells is more effective than indirect killing with apoptosis-inducing factors. ${ }^{36}$ It has also been demonstrated in metastatic breast, colorectal, and prostate cancer patients that NK cell cytotoxic activity was decreased in patients with a relatively high number of CTCs in peripheral blood compared to patients with a relatively low number of CTCs. ${ }^{37}$ Therefore, the increase of NK cell cytotoxic activity should be considered in future research as a treatment option in patients with relatively high numbers of CTCs.

There is increasing evidence that CTCs in the bloodstream can also associate with neutrophils. It has recently been demonstrated that CTCs in breast cancer patients were frequently associated with neutrophils and that this association drives cell cycle progression within the bloodstream 
and expands the metastatic potential of CTCs. ${ }^{34}$ Neutrophils seem to mediate adhesion of cancer cells and facilitate their extravasation (Figure 1), as demonstrated by several in vivo studies showing CTC interaction with endothelium-bound neutrophils in the vascular network and their promotion of adhesive and migratory activity through different molecular targets. ${ }^{38-41}$

Two subpopulations, classical and non-classical monocytes are also found in the circulation. Whereas classical monocytes can extravasate and differentiate into macrophages with protumor and prometastatic functions, non-classical monocytes display a protective role against metastasis. They accumulate in the capillaries in response to chemokines and clear cellular debris. ${ }^{42} \mathrm{~A}$ preclinical study on mouse tumor models has demonstrated that after tumor cells injection, non-classical monocytes were recruited to premetastatic lung capillaries in response to chemokine CX3CL1, where they engulfed tumor material and secreted CCL3, CCL4 and CCL5, leading to the activation of NK cells. ${ }^{43}$

CTCs also interact with the adaptive arm of the immune system. However, our current knowledge concerning the function of lymphocytes in immune surveillance of CTCs is very limited. It was shown that in patients with metastatic breast cancer low circulating lymphocyte levels and high CTC levels were found to be independent predictive factors of poor diagnosis, progression-free survival and overall survival. ${ }^{44}$ Similarly, low percentage of lymphocytes were found in patients with inflammatory breast cancer and advanced non-small-cell lung cancer (NSCLC), which could contribute to immune evasion. ${ }^{45,46}$ Several studies in patients with different types of cancer have also shown that CTCs frequently express PD-L1, one of the mechanisms responsible for CTC escape from immune surveillance. ${ }^{47-49}$ Further studies are needed in this field, however, monitoring of PD-L1 expression in CTCs could be used in the future as a prognostic biomarker or/and as predictive biomarker for checkpoint inhibitor-based immunotherapy. ${ }^{50-52}$

\section{Extravasation and colonization of distant tissues}

In contrast to the short half-life of CTCs in the blood, the metastatic process takes months and years. ${ }^{53}$ Cancer cells spread throughout the body and leave the circulation at potential secondary tumor sites in a process called extravasation. Extravasation requires tumor cells to traverse the endothelial wall in the process of transendothelial migration. ${ }^{54}$ The ability of CTCs to extravasate can be influenced by several factors, such as monocytes, which may differentiate into metastasis-associated macrophages, or platelets which release ATP and increase the permeability of the capillary walls. ${ }^{55,56}$ Extravasation of CTCs takes place in small capillaries with a diameter similar to that of the CTC. In this manner, the CTCs are trapped in the vessel. The first step of extravasation thus appears to be the stopping and physical restriction of a CTC in the vessel and subsequent attachment to the endothelium. ${ }^{57}$ Adhesion to the endothelium requires the expression of ligands and receptors on cancer cells and endothelial cells, such as selectins, integrins, cadherins, antigen CD44 and immunoglobulin superfamily receptors. The cancer cells or cancer cell-related leukocytes release cytokines that promote E-selectin expression on the endothelial cell surface. ${ }^{54} \mathrm{~A}$ CTC then binds to an E-selectin molecule on the endothelium. ${ }^{58}$ Different tumor types exhibit different metastatic patterns, a phenomenon termed tissue tropism. ${ }^{53}$ These patterns are largely dependent on the vasculature of the secondary organ and the chemokines and their receptors expressed between the target endothelium and the cancer cells. ${ }^{54,59}$ In addition to E-selectin expression on endothelial cell surface, chemokines also play an important role in CTC and endothelial interaction. Chemokines are released by the target tissue to attract tumor cells. The role of the chemokine C-X-C motif 12 ligand (CXCL12), also called stromal-derived factor- $1 \alpha$ (SDF-1 $\alpha)$, has been extensively investigated. The ligand is produced by stromal cells. ${ }^{60}$ It then binds to its receptors C-X-C motif chemokine receptor 4 (CXCR 4) and C-X-C motif chemokine receptor 7 (CXCR 7) on cancer cells. In vitro stimulation by the CXCL12 increased interactions of pancreatic and prostate cancer cells with the endothelium and the subsequent trans-endothelial migration. ${ }^{61}$

The attachment of a cancer cell to the E-selectin molecule is followed by interactions via integrins, CD44 antigen and mucin 1 (MUC1), contributing to a more stable attachment to the endothelial cell. This is followed by transendothelial migration, which can take place paracellularly or transcellularly. In vitro, most cells use the paracellular route $^{54}$, in which the opening of tight endothelial cell-junctions is initiated by factors released by either the tumor or the immune cells, such as TGF $\beta$ and VEGF ${ }^{62,63}$, however, it is not known which the preferred route is in vivo. The subsequent crossing of the tumor cell through the basal lamina is 
the final step in the process of extravasation. If not eliminated, the newly extravasated cells can then enter a state of dormancy or proliferate in this new microenvironment to form metastases. The vast majority of tumor cells undergo cell death after extravasation. ${ }^{54}$

Similarly to primary tumors, newly formed micrometastases depend on stromal support to survive. ${ }^{64}$ The transition of tumor cells from dormant state to proliferation can be provoked by changes in the tumor microenvironment, such as angiogenesis. ${ }^{57}$ Another factor might be the induction of inflammation, as described by the De Cock et al. ${ }^{65}$ In 2017, a Chinese study similarly reported that CTCmediated systemic inflammation and neutrophil recruitment to pre-metastatic tissues is the mechanism of metastatic colonization by the CTCs. ${ }^{66}$ This was demonstrated in vitro using an anti-inflammatory cytokine interleukin 37 (IL-37) to deplete neutrophils, suppress inflammatory response and thus the promoting effect of CTCs on tumor metastasis. ${ }^{66}$ The mechanism is based on the assumption of functional plasticity of neutrophils in the tumor microenvironment. Depending on environmental factors, neutrophils can switch between anti-tumor and pro-tumor phenotypes. ${ }^{67}$ IL-37 was able to suppress CTC-induced conversion of neutrophil function to pro-tumor phenotype. These findings suggest anti-inflammatory therapy could be used when higher CTC count is detected. ${ }^{66}$

In addition, the support of the extracellular matrix (ECM) may also aid in metastatic colonization. Specific ECM components associated with colonization of the lung in breast cancer have been identified. ${ }^{68,69}$ Hypoxia and fibrosis have also been linked to metastasis. ${ }^{19,70}$ Interestingly, suitable microenvironment may start to develop prior to extravasation of tumor cells as a result of systemic effects of the primary tumor. ${ }^{19}$ An observation by CostaSilva et al. describes exosomes derived from tumor cells carrying DNA, mRNA, miRNA and proteins which prime the liver for metastasis of pancreatic ductal adenocarcinoma. ${ }^{71}$ These particles have become the focus of recent studies and may cause a broad spectrum of actions, such as immunosuppression and/or induction of angiogenesis, inflammation, extracellular remodeling, and metabolic reprogramming.

Apart from the above described factors, the survival of a cancer cell in this microenvironment is also dependent on its genetic profile. Some of the genes associated with increased survival of cancer cells in various secondary tissues have been identified. A study by Zhang et al. identified a popula- tion of breast cancer cells that do not express the EpCAM cell surface antigen, but do express human epidermal growth factor receptor 2 (HER2), EGFR, heparanase (HSPE) and Notch 1, and selectively metastasize to the brain. ${ }^{72}$ Genes that mediate metastases to the lung and bone have also been identified. ${ }^{73,74}$

\section{Liquid biopsy and CTC detection}

Distant metastases are the main cause of cancerrelated mortality. Following primary tumor removal, DTC and micrometastases can remain dormant for long periods of time before causing disease relapse and are thus termed minimal residual disease (MRD). ${ }^{75}$ DTCs cannot be detected by radiologic imaging. However, they can be studied by performing biopsies of their reservoirs. The bone marrow is considered to be the primary indicator of MRD and poor outcome. ${ }^{76}$ It can be accessed by an iliac crest biopsy. Because bone marrow biopsy is a highly invasive procedure, current research is focusing on clinical utility of CTCs in the blood. ${ }^{77} \mathrm{~A}$ method called the liquid biopsy allows the extraction and testing of blood for tumor cell presence, and is able to detect CTC, cell free DNA (cfDNA), cell free RNA (cfRNA), microRNA (miRNA) and exosomes.

Detection of CTCs in a blood sample is challenging as these cells are present in very small numbers and are surrounded by billions of other blood cells (1 CTC per $10^{7}$ of leukocytes per $\mathrm{ml}$ of blood). ${ }^{78}$ Highly sensitive and specific analytical methods are required, which can be achieved by using capture, enrichment and detection procedures. ${ }^{79}$ Most isolation devices combine capture and enrichment procedures and may also include detection and enumeration technology. Capture procedures aim to overcome the low specificity of a regular blood draw by increasing its yield. The GILUPI nanodetector $\subseteq$ detects and captures CTC in the blood in vivo. The detector is located on a steel wire and is covered by chimeric anti-EpCAM antibodies. The device is inserted through a standard venous cannula into a peripheral vein for 30 minutes. During this time, the $2 \mathrm{~cm}$ functional area of the detector will come into contact with up to 1.5 litres of blood, enabling contact with a significantly larger amount of CTCs than during a regular blood draw. After removal, CTCs can be identified via immunocytochemical staining and counted. This protocol has been tested in patients with breast cancer and non- 
small cell lung cancer (NSCLC) with no adverse effects. ${ }^{80}$

Enrichment procedures aim to increase the percentage of CTCs in the sample. They are based on various properties of CTCs that distinguish them from the surrounding normal hematopoietic cells. These properties are either physical (size, density, electric charge, deformability) or biological (cellsurface protein expression and viability). Physical properties of the CTCs are the functional basis of membrane filters (size), microfluidic systems (deformability), density gradient centrifugation (density), and dielectrophoresis (electric charge). Biological properties are exploited by the immunobead assays, which use antibodies against tumor or non-tumor associated antigens, and microdevices. ${ }^{81}$ Isolation of CTCs based on their physical properties has certain advantages. They do not rely on biomarker expression, thus the isolated cells are viable, intact and can be used for further in vitro characterization and experiments. Enrichment time is short, and the cost of the procedure is low because ligands for CTC capture are not required. On the other hand, the limitation of these technologies is their low specificity, which requires downstream procedures for purity analyses. ${ }^{79}$ Among these physical methods, size-based isolation of CTCs takes advantage of their increased size (12$25 \mu \mathrm{m})$ compared to leukocytes $(5-20 \mu \mathrm{m}){ }^{82}$ Sizebased isolation of CTCs includes membrane microfilters and size-based microfluidic CTC sorting devices. ${ }^{83}$ Isolation by size of epithelial tumor cells (ISET) technology uses polycarbonate microfilters of $8 \mu \mathrm{m}$ diameter pores for CTC enrichment. ${ }^{84}$ The CTC sorting system Parsortix $($ is designed as a channel with stepped obstacles that progressively decrease as the cells in suspension flow through it. Both size and deformability contribute to successful CTC isolation. $10-\mu \mathrm{m}$ was set as cut-off size for cancer cells isolation. The main advantage of the device is high capture purity and isolation of viable cancer cells. ${ }^{85}$ Density gradient centrifugation for separation of different cell types was observed by S.H. Seal in $1959 .{ }^{86}$ From top to bottom, centrifugation yields the following layers: erythrocytes, granulocytes, density gradient, buffy coat with mononuclear cells and CTCs, and plasma. AccuCyte $\odot$ is an advanced density-gradient separation technology combining a separation tube and a collector device, which allows buffy coat collection into a small volume. The collected layer can be applied to a microscopic slide without cell lysis or wash steps with possible loss of CTC. ${ }^{87}$ Another recently validated technology is a microfluidic chip that is able to focus and capture CTCs with high cell yield and without the need for further purification. In the course of the validation study, single CTCs, CTC clusters and tumor microemboli (observed as multicellular tumour aggregates of CTC and white blood cells) were identified in patients with head and neck cancer. ${ }^{88}$

Biological property that is the most widely used for enrichment of CTCs is based on positive immunoselection. Specific cell-surface antigen expression in CTCs from epithelial carcinomas versus leukocytes allows for positive selection of CTCs. Specific antibodies are added to a blood sample to mark tumor cell-specific cell-surface markers, most commonly the EpCAM, which is a transmembrane glycoprotein expressed by the majority of tumors of epithelial origin. Other positive selection antibodies include anti HER2 and anti EGFR. On the other hand, a negative immunoselection of leukocytes based on their biological characteristics can also lead to enrichment of CTCs. The most commonly used negative selection target is the leukocyte antigen CD45.81,89 The enrichment step should be followed by tumor cell detection and verification. In most methods, this step includes immunofluorescence staining and high-resolution imaging. A certain amount of leukocytes is still present in the enriched fraction and single-cell level identification is required. Most of the established CTC assays use cytokeratin (CK), CD45 and nuclear dye 4,6-diamidino-2-phenylindole (DAPI) staining. Fluorescence microscopy should identify stained CTCs as CK positive, CD45 negative and DAPI positive. ${ }^{81}$ An alternative to immunocytochemical staining are real-time polymerase chain reaction (RT-PCR) assays based on the detection of mRNA expression. ${ }^{90,91}$ CellSearch $\odot$ is an established immunomagnetic CTC isolation assay, which uses magnetic beads covered with anti-EpCAM antibodies for positive selection. CTC separation and magnetic bead washing is followed by secondary selection based on morphology, CK staining and CD45 antigen expression. The CellSearch $\odot$ is the only CTC isolation assay to have been approved by the Food and Drug Administration (FDA) as a prognostic tool in the management of breast cancer, prostate cancer and colorectal cancer patients. ${ }^{92}$

An important concern is the fact that most CTC isolation technologies are based on epithelial cellsurface marker detection, because mesenchymal markers are expressed in white blood cells. In this way, a potentially crucial CTC population which expresses mesenchymal markers and is related to a more aggressive disease course could be over- 
looked. ${ }^{93}$ Detection protocols should be improved in order to optimize selection based on a combination of EMT and cancer cell markers.

\section{Clinical applications}

Clinical oncology has always faced limitations due to disease heterogeneity. The diagnostics of a tumor biopsy sample is deficient in case of gross tumor heterogeneity and the therapy prescribed might not be the most suitable option for the patient. Different tumor subpopulations, including distant metastases, can express various molecular targets, resulting in poor response to therapy and contributing to the development of drug resistance. These challenges could be solved by regular monitoring of CTCs and their products in the circulation by performing a liquid biopsy, thus allowing disease course surveillance, detect emerging drug resistance, recognition of new molecular targets and defining disease status in real time. CTCs contribute greatly to the metastatic process and are as such a promising target for early cancer detection, prognosis-oriented testing as well as personalized cancer therapy (Figure 2). The following text summarizes the aspects of CTC utility in clinical medicine.

\section{Screening}

Studies that investigate screening usually start by comparing patients with cancer with controls

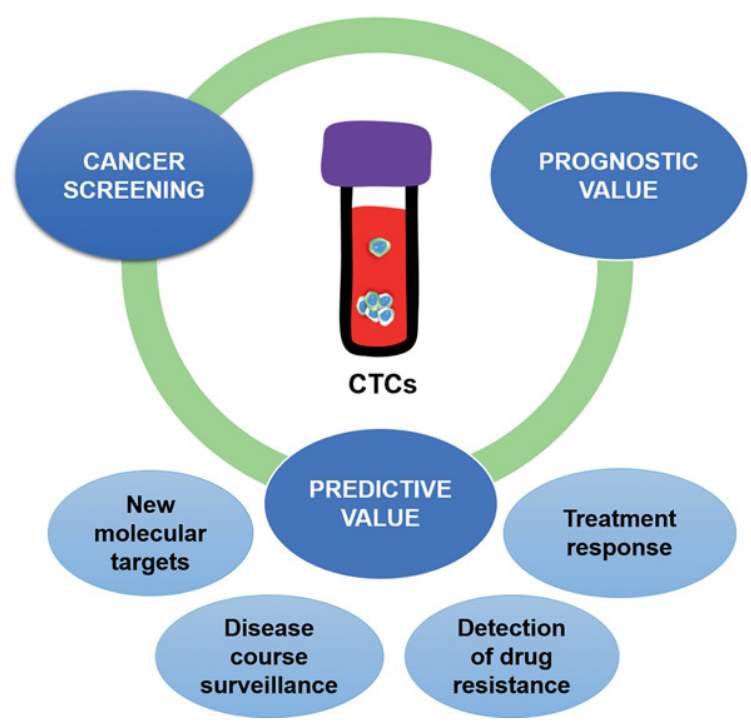

FIGURE 2. Clinical applications of CTCs. (healthy individuals or patients with benign diseases). Subsequent cohort studies are cumbersome and require large study populations and extended follow-up times. Focusing on screening of patients with high risk of developing cancer is a good strategy to speed up the clinical validation process. ${ }^{94}$

In 2004, a milestone study showed circulating epithelial cells to be extremely rare in healthy women, never reaching more than 2 cells per $7.5 \mathrm{ml}$ of blood. ${ }^{95}$ However, higher circulating epithelial cell levels were observed in patients with benign inflammatory bowel disease, such as diverticulosis and Crohn's disease, and in patients with elevated prostate specific antigen (PSA) values. ${ }^{96,97}$ The utility of CTCs for screening is therefore limited by its low sensitivity and specificity. But there are studies in selected populations where CTC screening might be applicable. In patients with chronic obstructive pulmonary disease (COPD), a major risk factor for lung cancer, CTCs were detected 1-4 years earlier than radiologic signs of malignancy could be found on a computed tomography scan. ${ }^{98}$ Interestingly, CTCs detected in patients with COPD had a heterogeneous expression of epithelial and mesenchymal markers. These preliminary findings need to be validated in larger cohorts, and sources that may lead to unspecific findings in non-cancer patients, such as the release of epithelial cells into the blood of patients with inflammatory bowel diseases, need to be identified. On the other hand, CTC values over 25 cells per $7.5 \mathrm{ml}$ of blood could be used to distinguish lung carcinoma from benign lesions in patients with suspicious radiological findings, as demonstrated by a study using sizebased isolation on ScreenCell Cyto filtration device and subsequent immunohistochemistry. ${ }^{99}$

\section{Prognostic value}

Numerous studies have thus far demonstrated the prognostic significance of CTC in patients with various types of solid tumors, most notably breast cancer. Interestingly, the 2010 TNM classification of malignant tumors already included a new stage called cM $0(\mathrm{i}+)$, with " $\mathrm{i}+$ " referring to isolated tumor cells detection in blood, bone marrow, and lymph nodes. ${ }^{100}$ In clinical practice however, this classification stage is rarely used, most notably due to low CTC counts in M 0 patients, which has raised doubts about their utility as a reliable marker. ${ }^{94}$ Nevertheless, there is increasing evidence that the determination of CTC counts before or after initial surgery in M0 patients is a reliable indicator of an unfavorable prognosis. ${ }^{94}$ 
Patients with detectable CTCs are known to have shorter overall survival (OS) and progression free survival (PFS). ${ }^{101-107}$ CTCs can also help evaluate MRD and select patients who are more at risk for relapse. ${ }^{108,109}$ Patients with high CTC levels during chemotherapy have significantly shorter survival. Metastatic patients with high baseline CTC counts that decrease after one cycle of chemotherapy have better prognosis. ${ }^{104,106,110-112}$

Additional prognostic information can be obtained from morphological properties of CTCs. Patients with apoptotic CTCs or CTC clusters in blood samples after systemic therapy initiation had worse prognosis in terms of PFS and OS than patients with CTCs without these properties, indicating morphological characterization of CTCs could be an important prognostic marker during therapy in patients with $\geq 5$ CTC per $7.5 \mathrm{ml}$ blood. ${ }^{113}$

\section{Predictive value}

CTCs are a heterogeneous group of cells subjected to dynamic changes. The population of CTCs is rapidly being replaced by new circulating cells from different cell reservoirs, be it primary tumor or metastatic sites, thus mirroring the changes in systemic disease in real time. The main objectives of studies assessing the clinical applications of CTCs are: their possible role as a surrogate tumor sample for liquid biopsy; changes in CTC counts and properties during therapy as an indicator of response to therapy, and targeting CTC- and metastasis-related features. ${ }^{89}$

CTCs as surrogate material for biopsy can help determine the risk of relapse and guide adjuvant therapy. Despite the fact, that many localized cancers can be cured by surgery only, some patients still experience late relapse. This is hypothesized to be the result of the presence of MRD of different carcinomas, which has no sensitive and specific enough biomarker. A study in colon cancer patients demonstrated that $72.5 \%$ of CTC-positive patients experienced relapse after surgery compared to $12 \%$ of patients with no detected CTCs. Using CTC presence in the bloodstream, patients with MRD could be identified and given adjuvant chemotherapy. ${ }^{114,115}$ An intriguing study from 2018 investigated the benefit of radiotherapy in early stage breast cancer patients who underwent breast conserving surgery based on their CTC status. They found longer overall survival in patients with detectable CTCs that received radiotherapy. Radiotherapy did not influence overall survival in patients with no detectable CTCs. This is the first identified predictive factor for the therapeutic benefit of radiotherapy. ${ }^{116}$ Liquid biopsy can also be used to monitor patients during therapy as a surrogate marker for response to therapy, as confirmed by studies in prostate and breast cancer patients. ${ }^{117-119}$ CTC levels can also be used to monitor response to anti-tumor vaccines and immunotherapy. ${ }^{120,121}$ Molecular targets expressed by CTCs are not necessarily the same than those expressed by the primary tumor and could be used to guide targeted therapy. Evaluation of HER2, estrogen receptor (ER) and progesteron receptor (PR) status on CTCs in breast cancer patients has been extensively studied, but no standardized method or consensus on positivity criteria has been provided. ${ }^{122}$

In current clinical practice, the expression of these markers on primary tumor tissue/based on primary tumor biopsy is used to guide treatment and prognosis, which is why a CTC-guided approach would have great clinical utility. ${ }^{123}$ Agreement of ER and PR expression on CTCs and the corresponding primary tumor ranges from 40 to $70 \%{ }^{122,124-127}$ A study of HER2 expression on CTCs in early breast cancer patients also showed frequent discordance between the HER2 expression of CTCs and that of the primary tumor. ${ }^{128}$ Administration of trastuzumab was able to eliminate chemotherapyresistant CK19 mRNA-positive CTCs and prolong disease-free survival (DFS) compared to observation in a breast cancer population with HER2 negative primary tumors and detectable CK19 mRNApositive CTCs before and after adjuvant therapy, of who $89 \%$ had HER2-positive CTCs. ${ }^{129}$

A recent study found PD-L1 is evaluable in CTCs of patients with NSCLC and head and neck cancer, while it is predictive of poorer outcomes only in head and neck cancer. ${ }^{130}$ Another recent study reported PD-L1 expression only in CTCs in contrast to primary tumor tissue samples. ${ }^{52}$

On the other hand, androgen receptor variant 7 (AR-V7) expression on CTCs in metastatic castration resistant prostate cancer patients was identified as a biomarker for superior clinical outcomes on taxane therapy, indicating it may serve as a treatment selection (predictive) biomarker. ${ }^{131}$ Other studied biomarkers include EGFR and CD133, which is a potential chemoresistance marker. ${ }^{132,133}$ Further multicenter clinical trials are needed to define the role of expression of different targets on CTCs for patient selection.

In 2013, patient-derived CTC cultures were first established $^{134}$, though implementation of the procedure into regular clinical practice has proven to be difficult due to the low efficiency of available 
detection methods as well as prolonged periods needed to establish cell lines. ${ }^{135}$ CTC-based patientderived xenografts represent an innovation in cancer research with the potential to guide therapy or pre-clinical drug testing and biomarker identification. CTCs are isolated from the patient's blood and injected into immunocompromised animals. Subsequently generated xenografts can be used for functional testing or as a bioptic sample for molecular characterization. This experimental model has been successfully tested in prostate cancer, small cell lung cancer and breast cancer patients and represents another important step towards personalized medicine. ${ }^{136-139}$

\section{Clinical applications in specific cancer types}

In breast cancer, the presence of 5 or more CTCs per $7.5 \mathrm{ml}$ of blood has been associated with a reduction in progression free survival, overall survival ${ }^{95,140-142}$, as well as with higher disease progression and mortality of metastatic breast cancer patients. ${ }^{143-147}$ Moreover, in metastatic breast cancer patients, evidence suggests that CTC detection can be an earlier indicator of disease change compared to radiologic changes. ${ }^{148}$ Nevertheless, in metastatic breast cancer patients, detection of CTCs appears to be metastatic site dependent, with a positive correlation with brain metastases and an inverse correlation with bone metastases. ${ }^{149}$ In spite of the prognostic value of CTC detection, switching to an alternate chemotherapy has not shown to prolong survival time. ${ }^{150}$ Underestimation of CTC count is probably the result of epithelial cell marker loss after EMT, which is believed to be paramount for cell dissemination and chemotherapy resistance. ${ }^{151-153}$ In HER2-positive patients treated with HER2targeting therapy, detected levels of CTCs seem to have no prognostic value. ${ }^{154}$ In triple-negative metastatic breast cancer patients on the other hand, the CTCs levels have been reported to carry a significant negative prognostic value. ${ }^{127,155}$

In non-metastatic breast cancer, clinical utility of CTC detection remains a topic of discussion, as the detected values and their incidence are lower than in metastatic breast cancer cases. ${ }^{156}$ Still, a pooled analyses showed strong evidence in favor of the independent prognostic value of CTC detection in estimating disease-free, overall, breast cancer-specific, and distant disease-free survival. ${ }^{105}$ Moreover, in non-metastatic breast cancer, positive CTC results before treatment were related to lymph node metastasis, and were shown to have a significant prognostic impact on disease-free and overall survival. ${ }^{157}$ The fact that the detected presence of CTCs does not correlate with any established clinico-pathologic parameters demonstrates the value of additional independent information provided by the method. ${ }^{158-162}$ CTC detection also shows promise in neoadjuvant therapy and provides a rapid way to assess the therapeutic efficacy. ${ }^{156}$ CTC detection before neoadjuvant setting carry an independent prognostic value for a reduced disease-free and overall survival ${ }^{163}$, while not being associated with pathologic complete response $^{164,165}$, again demonstrating the method's independent prognostic value. ${ }^{156}$ Current research is focused also on investigating possible therapeutic targets on CTCs. ${ }^{156}$

Multiple large phase II and III trials have established the prognostic value of CTC in advanced prostate cancer, most notably metastatic castration-resistant prostate cancer. ${ }^{112,166-170}$ The value of $\geq 5$ CTCs per $7.5 \mathrm{ml}$ of blood demonstrates a cutoff point with a significantly altered overall survival in metastatic castration-resistant prostate cancer patients. ${ }^{112,168-170}$ Measured prior to, during and following cytotoxic therapy in castration-resistant prostate cancer, CTC detection has been shown to be the strongest independent predictor of overall survival. ${ }^{112,166}$ A conversion from unfavorable to favorable CTC baseline concentrations (or vice versa) during chemotherapy, reflects disease outcome. ${ }^{112,168}$ The method of CTC detection has even been shown superior to PSA measurements, both in the rapidity of detectable change as well as reliability, and has consequently been approved by the Food and Drug Administration for prostate cancer therapy monitoring in 2008. ${ }^{112}$ In addition, it is recommended that therapy should not be changed based on PSA values alone. ${ }^{171}$ Fixed cutoff values simplify therapeutic decision-making. Nevertheless, strong evidence exists in favor of the assumption that patient survival is independent of a specific CTC concentration threshold. ${ }^{166,172}$ Also, treatment should be continued regardless of the cutoff value of $\geq 5$ CTCs per $7.5 \mathrm{ml}$ of blood, as long as CTC levels remain stable or decrease under therapy. Similarly, an increase in CTC concentrations may indicate primary treatment resistance and warrant therapy switch. ${ }^{156}$ In estimation of treatment effectiveness, CTC detection coupled with lactate dehydrogenase measurements has been shown superior to baseline serum lactate dehydrogenase measurements alone. ${ }^{166}$ While CTC isolation has been extensively studied in castration 
resistant prostate cancer, relevance in other disease stages such as hormone sensitive or early prostate cancer are still scarce. ${ }^{156}$ Patients in these disease stages present with infrequent and low CTC counts (1-2 on average) show no correlation with other established clinicopathologic parameters (Gleason grade, PSA, TNM staging). $\cdot{ }^{97,173-175}$ In hormone sensitive metastatic prostate cancer, cutoff values of $\geq$ 5 CTCs per $7.5 \mathrm{ml}$ of blood ${ }^{176,177}$ have been shown to anticipate lower hormone deprivation responsiveness and shortened transition times to castrationresistant prostate cancer, associated with shorter progression free survival and overall survival. ${ }^{178}$ This could indicate the aggressiveness of the disease and resultantly warrant closer monitoring and earlier treatment switches. ${ }^{156}$

In non-metastatic urinary carcinoma of the bladder, detection of CTCs correlates positively with worse progression free survival, overall survival, cancer-specific survival ${ }^{179}$ as well as recurrencefree survival ${ }^{180}$, and is a an independent prognostic factor for early systemic disease ${ }^{180}$, both in cases of pure and variant urinary carcinoma of the bladder. ${ }^{181}$ Moreover, a comparison between CTC and primary tumor HER2 status showed dissimilarities in $23 \%$ of cases, pointing out a possible benefit of HER2-targeting therapy in selected patients. ${ }^{180}$

Presently, the presence of CTCs in patients with seminomal and non-seminomal testicular germ cell tumors is not well established ${ }^{156}$, and has been associated with the tumor stage, elevated serum levels of alpha-fetoprotein and beta-human chorionic gonadotropin. ${ }^{182}$

In spite of frequent EpCAM negativity of renal cell cancer ${ }^{183}$, one study detected CTCs in $16 \%$ of subjects with metastatic renal cell carcinoma. ${ }^{184}$

The incidence of CTCs in metastatic colorectal cancer has been shown to be higher than in nonmetastatic disease, and correlates well with both progression free survival and overall survival, thus demonstrating the prognostic utility of the method. ${ }^{185}$ In newly diagnosed non-metastatic colorectal cancer, a higher presence of CTCs before surgery shows a good correlation with shorter relapse-free survival and cancer specific survival. ${ }^{185}$

Higher CTC levels following therapy in gastric and esophageal cancer are associated with worse prognosis. ${ }^{156}$

In pancreatic cancer, the presence of CTCs at baseline is an independent prognostic factor for overall survival ${ }^{107}$, with higher detection rates in metastatic disease compared to non-metastatic disease. ${ }^{156}$ Moreover, CTC detection in the portal vein has been associated with higher rates of liver metastases after surgery in contrast to detection in peripheral blood. ${ }^{186}$ Compared to other types of carcinoma, pancreatic cancer CTC detection rates are thought to be lower due to CTC sequestration by the liver, decreased vascularity in aggressive tumors and the inability to detect CTCs following EMT. $^{187}$

As in other tumor types, CTCs in cholangiocarcinoma were detected and correlated with shorter overall survival. ${ }^{188}$

CTC concentration is approximately ten times higher in small cell lung cancer compared to that in NSCLC. ${ }^{156}$ CTC detection of $\geq 50$ CTCs per $7.5 \mathrm{ml}$ of blood in small cell lung cancer patients prior to chemotherapy is associated with a shorter progression free survival and overall survival. ${ }^{104}$ Similar is true for the incidence of metastases to other organs, especially liver. ${ }^{189}$ CTC enumeration has also been used to discriminate between localized (median 6 CTCs/7.5 ml of blood) and extensive (median 63 CTCs/7.5 ml of blood) disease at baseline. ${ }^{190}$ CTC $\geq 5$ per $7.5 \mathrm{ml}$ of blood is an independent negative prognostic factor in NSCLC. ${ }^{104,156,190}$

Decreasing values of detected CTCs in patients undergoing chemotherapy could carry a predictive value for therapy response in cancer of unknown primary origin. ${ }^{191}$

Several studies investigating the viability of CTC based disease detection and monitoring in gynecologic, head and neck, neuroendocrine tumors and melanomas, have shown poor clinical outcomes in cases of CTC detection. ${ }^{156}$

\section{Conclusions}

The management of a cancer patient is based on radiological evidence and histopathological properties of the primary tumor. Cancer is a constantly evolving disease prone to selection pressure caused by therapy. By relying on the biopsy of the tumor, our insight into the patient's disease is both spaceand time-limited, resulting in insufficient information for proper patient management. The concept of a liquid biopsy enables real-time disease control while being both more accessible and less invasive for the patient. The number of CTCs in the blood is a strong prognostic factor and can be used for monitoring response to therapy. In addition, detection of specific molecular targets on CTCs can improve and guide novel treatment approaches. Isolated CTCs can be used to analyze DNA, RNA or proteins produced by the tumor cell. Furthermore, they can be used to produce patient-derived xen- 
ografts for functional testing. On the other hand, CTC detection faces its limitations because of the rarity of these cells compared to the background of billions of normal blood cells. Highly sensitive and specific methods are required for successful isolation and detection. With the development of better CTC isolation technologies and clinical testing in large prospective trials, increasing clinical utility of CTCs can be expected. The understanding of their biology and interactions with the immune system and the rise of immunotherapy also hold great promise for novel therapeutic possibilities.

\section{Acknowledgement}

The authors acknowledge the financial support from the state budget by the Slovenian Research Agency (program no. P3-0003, P3-0321 and project no. Z3-8204).

\section{References}

1. Ashworth T. A case of cancer in which cells similar to those in the tumours were seen in the blood after death. Aust Med J 1869; 14: 146-7.

2. Riethdorf S, Pantel K. Disseminated tumor cells in bone marrow and circulating tumor cells in blood of breast cancer patients: current state of detection and characterization. Pathobiology 2008; 75: 140-8. doi: 10.1159/000123852

3. Butler TP, Gullino PM. Quantitation of cell shedding into efferent blood of mammary adenocarcinoma. Cancer Res 1975; 35: 512-6. PMID: 1090362

4. Fabisiewicz A, Grzybowska E. CTC clusters in cancer progression and metastasis. Med Oncol 2017; 34: 12. doi: 10.1007/s12032-016-0875-0

5. Aceto N, Bardia A, Miyamoto DT, Donaldson MC, Wittner BS, Spencer JA et al. Circulating tumor cell clusters are oligoclonal precursors of breast cancer metastasis. Cell 2014; 158: 1110-22. doi: 10.1016/j.cell.2014.07.013

6. Cheung KJ, Padmanaban V, Silvestri V, Schipper K, Cohen JD, Fairchild AN et al. Polyclonal breast cancer metastases arise from collective dissemination of keratin 14-expressing tumor cell clusters. Proc Natl Acad Sci 2016; 113: E854-63. doi: 10.1073/pnas.1508541113

7. Giampieri S, Manning C, Hooper S, Jones L, Hill CS, Sahai E. Localized and reversible TGF $\beta$ signalling switches breast cancer cells from cohesive to single cell motility. Nat Cell Biol 2009; 11: 1287-96. doi: 10.1038/ncb1973

8. Kalluri R, Weinberg RA. The basics of epithelial-mesenchymal transition. $J$ Clin Invest 2009; 119: 1420-8. doi: 10.1172/JCl39104

9. Thiery JP, Sleeman JP. Complex networks orchestrate epithelial-mesenchymal transitions. Nat Rev Mol Cell Biol 2006; 7: 131-42. doi: 10.1038/ nrm1835

10. Kumar S, Das A, Sen S. Extracellular matrix density promotes EMT by weakening cell-cell adhesions. Mol Biosyst 2014; 10: 838-50. doi: 10.1039/ c3mb70431a

11. Craene B De, Berx G. Regulatory networks defining EMT during cancer initiation and progression. Nat Rev Cancer 2013; 13: 97-110. doi: 10.1038/ nrc3447

12. Yao D, Dai C, Peng S. Mechanism of the mesenchymal-epithelial transition and its relationship with metastatic tumor formation. Mol Cancer Res 2011; 9: 1608-20. doi: 10.1158/1541-7786.MCR-10-0568

13. Jolly MK, Boareto M, Huang B, Jia D, Lu M, Ben-Jacob E, et al. Implications of the hybrid epithelial/mesenchymal phenotype in metastasis. Front Oncol 2015; 5: 155. doi: 10.3389/fonc.2015.00155
14. Lecharpentier A, Vielh P, Perez-Moreno P, Planchard D, Soria JC, Farace F. Detection of circulating tumour cells with a hybrid (epithelial/mesenchymal) phenotype in patients with metastatic non-small cell lung cancer. $\mathrm{Br}$ J Cancer 2011; 105: 1338-41. doi: 10.1038/bjc.2011.405

15. Armstrong AJ, Marengo MS, Oltean S, Kemeny G, Bitting RL, Turnbull JD, et al. Circulating tumor cells from patients with advanced prostate and breast cancer display both epithelial and mesenchymal markers. Mol Cancer Res 2011; 9: 997-1007. doi: 10.1158/1541-7786.MCR-10-0490

16. Grosse-Wilde A, Fouquier d'Hérouël A, McIntosh E, Ertaylan G, Skupin A, Kuestner RE, et al. Stemness of the hybrid epithelial/mesenchymal atate in breast cancer and its association with poor survival. PLoS One 2015; 10: e0126522. doi: 10.1371/journal.pone.0126522

17. Jolly MK, Mani SA, Levine H. Hybrid epithelial/mesenchymal phenotype(s): the "fittest" for metastasis? Biochim Biophys Acta 2018; 870: 151-7. doi: 10.1016/j.bbcan.2018.07.001

18. Wong SY, Hynes RO. Lymphatic or hematogenous dissemination: how does a metastatic tumor cell decide? Cell Cycle 2006; 5: 812-7. doi: 10.4161/ cc. 5.8 .2646

19. Lambert AW, Pattabiraman DR, Weinberg RA. Emerging biological principles of metastasis. Cell 2017; 168: 670-91. doi: 10.1016/j.cell.2016.11.037

20. Bockhorn M, Jain RK, Munn LL. Active versus passive mechanisms in metastasis: do cancer cells crawl into vessels, or are they pushed? Lancet Oncol 2007; 8: 444-8. doi: 10.1016/S1470-2045(07)70140-7

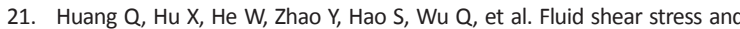
tumor metastasis. Am J Cancer Res 2018; 8: 763-77. PMID: 29888101

22. Stott SL, Lee RJ, Nagrath S, Yu M, Miyamoto DT, Ulkus L, et al. Isolation and characterization of circulating tumor cells from patients with localized and metastatic prostate cancer. Sci Transl Med 2010; 2: 25ra23. doi: 10.1126/ scitranslmed.3000403

23. Lou X-L, Sun J, Gong S-Q, Yu X-F, Gong R, Deng H. Interaction between circulating cancer cells and platelets: clinical implication. Chin J Cancer Res 2015; 27: 450-60. doi: 10.3978/j.issn.1000-9604.2015.04.10

24. Labelle M, Hynes RO. The initial hours of metastasis: the importance of cooperative host-tumor cell interactions during hematogenous dissemination. Cancer Discov 2012; 2: 1091-9. doi: 10.1158/2159-8290.CD-12-0329

25. Nieswandt B, Hafner M, Echtenacher B, Männel DN. Lysis of tumor cells by natural killer cells in mice is impeded by platelets. Cancer Res 1999; 59: 1295-300. PMID: 10096562

26. Franco AT, Corken A, Ware J. Platelets at the interface of thrombosis, inflammation, and cancer. Blood 2015; 126: 582-8. doi: 10.1182/ blood-2014-08-531582

27. Placke T, Orgel M, Schaller M, Jung G, Rammensee HG, Kopp HG, et al. Platelet-derived MHC class I confers a pseudonormal phenotype to cance cells that subverts the antitumor reactivity of natural killer immune cells. Cancer Res 2012; 72: 440-8. doi: 10.1158/0008-5472.CAN-11-1872

28. Kopp H-G, Placke T, Salih HR. Platelet-derived transforming growth factor - down-regulates NKG2D thereby inhibiting natural killer cell antitumor reactivity. Cancer Res 2009; 69: 7775-83. doi: 10.1158/0008-5472.CAN-092123

29. Labelle M, Begum S, Hynes RO. Direct signaling between platelets and cancer cells induces an epithelial-mesenchymal-like transition and promotes metastasis. Cancer Cell 2011; 20: 576-90. doi: 10.1016/j.ccr.2011.09.009

30. Mittal D, Gubin MM, Schreiber RD, Smyth MJ. New insights into cancer immunoediting and its three component phases - elimination, equilibrium and escape. Curr Opin Immunol 2014; 27: 16-25. doi: 10.1016/j. coi.2014.01.004

31. Vinay DS, Ryan EP, Pawelec G, Talib WH, Stagg J, Elkord E, et al. Immune evasion in cancer: mechanistic basis and therapeutic strategies. Semin Cancer Biol 2015; 35: S185-98. doi: 10.1016/j.semcancer.2015.03.004

32. Hiratsuka S, Watanabe A, Aburatani H, Maru Y. Tumour-mediated upregulation of chemoattractants and recruitment of myeloid cells predetermines lung metastasis. Nat Cell Biol 2006; 8: 1369-75. doi: 10.1038/ncb1507

33. Kim S, Takahashi $\mathrm{H}$, Lin $\mathrm{W}$-W, Descargues $\mathrm{P}$, Grivennikov $\mathrm{S}$, Kim $\mathrm{Y}$, et al. Carcinoma-produced factors activate myeloid cells through TLR2 to stimulate metastasis. Nature 2009; 457: 102-6. doi: 10.1038/nature07623 
34. Szczerba BM, Castro-Giner F, Vetter M, Krol I, Gkountela S, Landin J, et al. Neutrophils escort circulating tumour cells to enable cell cycle progression. Nature 1566: 553-7. doi: 10.1038/s41586-019-0915-y

35. Hanna N. Role of natural killer cells in control of cancer metastasis. Cancer Metastasis Rev 1982; 1:45-64.

36. Brodbeck T, Nehmann N, Bethge A, Wedemann G, Schumacher Perforin-dependent direct cytotoxicity in natural killer cells induces considerable knockdown of spontaneous lung metastases and computer modelling-proven tumor cell dormancy in a HT29 human colon cance xenograft mouse model. Mol Cancer 2014; 13: 244. doi: 10.1186/1476 4598-13-244

37. Santos MF, Mannam VKR, Craft BS, Puneky LV, Sheehan NT, Lewis RE, et al. Comparative analysis of innate immune system function in metastatic breast, colorectal, and prostate cancer patients with circulating tumor cells. Exp Mol Pathol 2014; 96: 367-74. doi: 10.1016/j.yexmp.2014.04.001

38. McDonald B, Spicer J, Giannais B, Fallavollita L, Brodt P, Ferri LE. Systemic inflammation increases cancer cell adhesion to hepatic sinusoids by neutrophil mediated mechanisms. Int J Cancer 2009; 125: 1298-305. doi: 10.1002/ijc.24409

39. Spicer JD, McDonald B, Cools-Lartigue JJ, Chow SC, Giannias B, Kubes P, et al. Neutrophils promote liver metastasis via Mac-1-mediated interactions with circulating tumor cells. Cancer Res 2012; 72: 3919-27. doi: 10.1158/0008-5472.CAN-11-2393

40. Huh SJ, Liang S, Sharma A, Dong C, Robertson GP. Transiently entrapped circulating tumor cells interact with neutrophils to facilitate lung metastasis development. Cancer Res 2010; 70: 6071-82. doi: 10.1158/0008-5472. CAN-09-4442

41. Strell C, Lang K, Niggemann B, Zaenker KS, Entschladen F. Neutrophil granulocytes promote the migratory activity of MDA-MB-468 human breas carcinoma cells via ICAM-1. Exp Cell Res 2010; 316: 138-48. doi: 10.1016/j. yexcr.2009.09.003

42. Auffray $C$, Fogg $D$, Garfa $M$, Elain $G$, Join-Lambert $O$, Kayal $S$, et al Monitoring of blood vessels and tissues by a population of monocytes with patrolling behavior. Science 2007; 317: 666-70. doi: 10.1126/science.1142883

43. Hanna RN, Cekic C, Sag D, Tacke R, Thomas GD, Nowyhed H, et al. Patrolling monocytes control tumor metastasis to the lung. Science 2015; 350: 985 90. doi: $10.1126 /$ science.aac9407

44. De Giorgi U, Mego M, Scarpi E, Giuliano M, Giordano A, Reuben JM, et al. Relationship between lymphocytopenia and circulating tumor cells as prognostic factors for overall survival in metastatic breast cancer. Clin Breast Cancer 2012; 12: 264-9. doi: 10.1016/j.clbc.2012.04.004

45. Mego M, Gao H, Cohen EN, Anfossi S, Giordano A, Sanda T, et al. Circulating tumor cells (CTC) are associated with defects in adaptive immunity in patients with inflammatory breast Cancer. J Cancer 2016; 7: 1095-104. doi: 10.7150/jca.13098

46. Ye L, Zhang F, Li H, Yang L, Lv T, Gu W, et al. Circulating tumor cells were associated with the number of T lymphocyte subsets and NK cells in peripheral blood in advanced non-small-cell lung cancer. Dis Markers 2017; 2017: 5727815. doi: 10.1155/2017/5727815

47. Mazel M, Jacot W, Pantel K, Bartkowiak K, Topart D, Cayrefourcq L, et al. Frequent expression of PD-L1 on circulating breast cancer cells. Mol Oncol 2015; 9: 1773-82. doi: 10.1016/j.molonc.2015.05.009

48. Kallergi G, Vetsika E-K, Aggouraki D, Lagoudaki E, Koutsopoulos A, Koinis $F$, et al. Evaluation of PD-L1/PD-1 on circulating tumor cells in patients with advanced non-small cell lung cancer. Ther Adv Med Oncol 2018; 10: 175883401775012. doi: 10.1177/1758834017750121

49. Oliveira-Costa JP, de Carvalho AF, da Silveira GG, Amaya P, Wu Y, Park K et al. Gene expression patterns through oral squamous cell carcinoma development: PD-L1 expression in primary tumor and circulating tumo cells. Oncotarget 2015; 6: 20902-20920. doi: 10.18632/oncotarget.3939

50. Yue $C$, Jiang $Y$, Li $P$, Wang $Y, X u e ~ J, ~ L i ~ N$, et al. Dynamic change of PD-L1 expression on circulating tumor cells in advanced solid tumor patients undergoing PD-1 blockade therapy. Oncoimmunology 2018; 7: e1438111. doi: $10.1080 / 2162402 X .2018 .1438111$

51. Nicolazzo C, Raimondi C, Mancini M, Caponnetto S, Gradilone A, Gandini $\mathrm{O}$, et al. Monitoring PD-L1 positive circulating tumor cells in non-small cell lung cancer patients treated with the PD-1 inhibitor nivolumab. Sci Rep 2016; 6: 31726. doi: 10.1038/srep31726
52. Guibert N, Delaunay M, Lusque A, Boubekeur N, Rouquette I, Clermont E, et al. PD-L1 expression in circulating tumor cells of advanced non-smal cell lung cancer patients treated with nivolumab. Lung Cancer 2018; 120: 108-12. doi: 10.1016/j.lungcan.2018.04.001

53. Micalizzi DS, Maheswaran S, Haber DA. A conduit to metastasis: circulating tumor cell biology. Genes Dev 2017; 31: 1827-40. doi: 10.1101/ gad.305805.117

54. Reymond N, d'Água BB, Ridley AJ. Crossing the endothelial barrier during metastasis. Nat Rev Cancer 2013; 13: 858-70. doi: 10.1038/nrc3628

55. Qian B, Deng Y, Im JH, Muschel RJ, Zou Y, Li J, et al. A distinct macrophage population mediates metastatic breast cancer cell extravasation, establishment and growth. PLoS One. 2009; 4: e6562. doi: 10.1371/journal. pone. 0006562

56. Schumacher D, Strilic B, Sivaraj KK, Wettschureck N, Offermanns S. Plateletderived nucleotides promote tumor-cell transendothelial migration and metastasis via P2Y2 receptor. Cancer Cell 2013; 24: 130-7. doi: 10.1016/j. ccr.2013.05.008

57. Kienast $\mathrm{Y}$, von Baumgarten L, Fuhrmann $\mathrm{M}$, Klinkert WE, Goldbrunner $\mathrm{R}$, Herms J, et al. Real-time imaging reveals the single steps of brain metastasis formation. Nat Med 2010; 16: 116-22. doi: 10.1038/nm.2072

58. Hiratsuka S, Goel S, Kamoun WS, Maru Y, Fukumura D, Duda DG, et al. Endothelial focal adhesion kinase mediates cancer cell homing to discrete regions of the lungs via E-selectin up-regulation. Proc Natl Acad Sci 2011; 108: 3725-30. doi: 10.1073/pnas.1100446108

59. Balkwill FR. The chemokine system and cancer. J Pathol 2012; 226: 148-57. doi: $10.1002 /$ path.3029

60. Kukreja P, Abdel-Mageed AB, Mondal D, Liu K, Agrawal KC. Up-regulation of CXCR4 expression in PC-3 cells by stromal-derived factor-1 $\alpha$ (CXCL12) increases endothelial adhesion and transendothelial migration: role of MEK/ ERK signaling pathway-dependent NF-KB activation. Cancer Res 2005; 65: 9891-8. doi: 10.1158/0008-5472.CAN-05-1293

61. Taichman RS, Cooper C, Keller ET, Pienta KJ, Taichman NS, McCauley LK Use of the stromal cell-derived factor-1/CXCR4 pathway in prostate cancer metastasis to bone. Cancer Res 2002; 62: 1832-7. http://www.ncbi.nlm. nih.gov/pubmed/11912162.

62. Hoeben A, Landuyt B, Highley MS, Wildiers H, Van Oosterom AT, De Bruijn EA. Vascular endothelial growth factor and angiogenesis. Pharmacol Rev 2004; 56: 549-80. doi: 10.1124/pr.56.4.3

63. Drabsch $Y$, ten Dijke P. TGF- $\beta$ signaling in breast cancer cell invasion and bone metastasis. J Mammary Gland Biol Neoplasia 2011; 16: 97-108. doi: 10.1007/s10911-011-9217-1

64. Wan L, Pantel K, Kang Y. Tumor metastasis: moving new biological insights into the clinic. Nat Med 2013; 19: 1450-64. doi: 10.1038/nm.3391

65. De Cock JM, Shibue T, Dongre A, Keckesova Z, Reinhardt F, Weinberg RA Inflammation triggers Zeb1-dependent escape from tumor latency. Cancer Res. 2016; 76: 6778-84. doi: 10.1158/0008-5472.CAN-16-0608

66. Li YC, Zou JM, Luo C, Shu Y, Luo J, Qin J, et al. Circulating tumor cells promote the metastatic colonization of disseminated carcinoma cells by inducing systemic inflammation. Oncotarget 2017; 8: 28418-30. doi: 10.18632/oncotarget.16084

67. Fridlender ZG, Sun J, Kim S, Kapoor V, Cheng G, Ling L, et al. Polarization of tumor-associated neutrophil phenotype by TGF- $\beta$ : "N1" versus "N2" TAN. Cancer Cell 2009; 16: 183-94. doi: 10.1016/j.ccr.2009.06.017

68. Oskarsson T, Acharyya S, Zhang XH-F, Vanharanta S, Tavazoie SF, Morris PG, et al. Breast cancer cells produce tenascin $C$ as a metastatic niche component to colonize the lungs. Nat Med 2011; 17: 867-74. doi: 10.1038/ $\mathrm{nm} .2379$

69. Malanchi I, Santamaria-Martínez A, Susanto E, Peng H, Lehr HA, Delaloye $\mathrm{JF}$, et al. Interactions between cancer stem cells and their niche govern metastatic colonization. Nature 2012; 481: 85-9. doi: 10.1038/nature10694

70. Barkan D, El Touny LH, Michalowski AM, Smith JA, Chu I, Davis AS, et al. Metastatic growth from dormant cells induced by a Col---enriched fibrotic environment. Cancer Res 2010; 70: 5706-16. doi: 10.1158/0008-5472. CAN-09-2356

71. Costa-Silva B, Aiello NM, Ocean AJ, Singh S, Zhang $\mathrm{H}$, Thakur BK, et al. Pancreatic cancer exosomes initiate pre-metastatic niche formation in the liver. Nat Cell Biol 2015; 17: 816-26. doi: 10.1038/ncb3169 
72. Zhang L, Ridgway LD, Wetzel MD, Ngo J, Yin W, Kumar D, et al. The identification and characterization of breast cancer CTCS competent for brain metastasis. Sci Transl Med 2013; 5: 180ra48. doi: 10.1126/scitransImed.3005109

73. Kang Y, Siegel PM, Shu W, Drobnjak M, Kakonen SM, Cordón-Cardo C, et al. A multigenic program mediating breast cancer metastasis to bone. Cancer Cell 2003; 3: 537-49.

74. Minn AJ, Gupta GP, Siegel PM, Bos PD, Shu W, Giri DD, et al. Genes that mediate breast cancer metastasis to lung. Nature 2005; 436: 518-24. doi: $10.1038 /$ nature03799

75. Uhr JW, Pantel K. Controversies in clinical cancer dormancy. Proc Nat/ Acad Sci 2011; 108: 12396-400. doi: 10.1073/pnas.1106613108

76. Braun S, Vogl FD, Naume B, Janni W, Osborne MP, Coombes RC, et al. A pooled analysis of bone marrow micrometastasis in breast cancer. $N$ Engl Med 2005; 353: 793-802. doi: 10.1056/NEJMoa050434

77. Pantel K, Alix-Panabières $C$, Riethdorf $S$. Cancer micrometastases. Nat Rev Clin Oncol 2009; 6: 339-51. doi: 10.1038/nrclinonc.2009.44

78. Krebs MG, Metcalf RL, Carter L, Brady G, Blackhall FH, Dive C. Molecular analysis of circulating tumour cells-biology and biomarkers. Nat Rev Clin Oncol 2014; 11: 129-44. doi: 10.1038/nrclinonc.2013.253

79. Shen Z, Wu A, Chen X. Current detection technologies for circulating tumo cells. Chem Soc Rev 2017; 46: 2038-56. doi: 10.1039/c6cs00803h

80. Saucedo-Zeni N, Mewes S, Niestroj R, Gasiorowski L, Murawa D, Nowaczyk $P$, et al. A novel method for the in vivo isolation of circulating tumo cells from peripheral blood of cancer patients using a functionalized and structured medical wire. Int J Oncol 2012; 41: 1241-50. doi: 10.3892/ ijo.2012.1557

81. Alix-Panabieres C, Pantel K. Circulating tumor cells: liquid biopsy of cancer. Clin Chem 2013; 59: 110-8. doi: 10.1373/clinchem.2012.194258

82. Hao S-J, Wan Y, Xia Y-Q, Zou X, Zheng S-Y. Size-based separation methods of circulating tumor cells. Adv Drug Deliv Rev 2018; 125: 3-20. doi:10.1016/j addr.2018.01.002

83. Ferreira MM, Ramani VC, Jeffrey SS. Circulating tumor cell technologies Mol Oncol 2016; 10: 374-94. doi: 10.1016/j.molonc.2016.01.007

84. Laget S, Broncy L, Hormigos K, Dhingra DM, BenMohamed F, Capiod $\mathrm{T}$, et al. Technical insights into highly sensitive isolation and molecula characterization of fixed and live circulating tumor cells for early detection of tumor invasion. Plos One 2017. 12: e0169427. doi: 10.1371/journal. pone.0169427

85. Hvichia GE, Parveen Z, Wagner C, Janning M, Quidde J, Stein A, et al. A novel microfluidic platform for size and deformability based separation and the subsequent molecular characterization of viable circulating tumor cells. Int J Cancer 2016; 138: 2894-904. doi: 10.1002/ijc.30007

86. Seal SH. Silicone flotation: A simple quantitative method for the isolation of free-floating cancer cells from the blood. Cancer 1959; 12: 590-5.

87. Rawal S, Yang Y-P, Cote R, Agarwal A. Identification and quantitation of circulating tumor cells. Annu Rev Anal Chem 2017; 10: 321-43. doi: 10.1146/ annurev-anchem-061516-045405

88. Kulasinghe A, Zhou J, Kenny L, Papautsky I, Punyadeera C. Capture of circulating tumour cell clusters using straight microfluidic chips. Cancers (Basel) 2019; 11: 89. doi: 10.3390/cancers11010089

89. Cabel L, Proudhon C, Gortais H, Loirat D, Coussy F, Pierga JY, et al. Circulating tumor cells: clinical validity and utility. Int J Clin Oncol 2017; 22 421-30. doi: 10.1007/s10147-017-1105-2

90. Guo M, Li X, Zhang S, Song H, Zhang W, Shang X, et al. Real-time quantitative RT-PCR detection of circulating tumor cells from breast cance patients. Int J Oncol 2015; 46: 281-9. doi: 10.3892/ijo.2014.2732

91. Katseli A, Maragos H, Nezos A, Syrigos K, Koutsilieris M. Multiplex PCRBased Detection of circulating tumor cells in lung cancer patients using CK19, PTHrP, and LUNX specific primers. Clin Lung Cancer 2013; 14: 513-20. doi: 10.1016/j.cllc.2013.04.007

92. Riethdorf S, Fritsche H, Muller V, Rau T, Schindlbeck C, Rack B, et al Detection of circulating tumor cells in peripheral blood of patients with metastatic breast cancer: a validation study of the CellSearch system. Clin Cancer Res 2007; 13: 920-8. doi: 10.1158/1078-0432.CCR-06-1695
93. Bednarz-Knoll N, Alix-Panabières C, Pantel K. Plasticity of disseminating cancer cells in patients with epithelial malignancies. Cancer Metastasis Rev 2012; 31: 673-87. doi: 10.1007/s10555-012-9370-z

94. Alix-Panabieres C, Pantel K. Clinical applications of circulating tumor cells and circulating tumor DNA as liquid biopsy. Cancer Discov 2016; 6: 479-91. doi: 10.1158/2159-8290.CD-15-1483

95. Cristofanilli M, Budd GT, Ellis MJ, Stopeck A, Matera J, Miller MC, et al. Circulating tumor cells, disease progression, and survival in metastatic breast cancer. N Engl J Med 2004; 351: 781-91. doi: 10.1056/ NEJMoa040766

96. Pantel K, Deneve E, Nocca D, Coffy A, Vendrell JP, Maudelonde T, et al. Circulating epithelial cells in patients with benign colon diseases. Clin Chem 2012; 58: 936-40. doi: 10.1373/clinchem.2011.175570

97. Davis JW, Nakanishi H, Kumar VS, Bhadkamkar VA, McCormack R, Fritsche $H A$, et al. Circulating tumor cells in peripheral blood samples from patients with increased serum prostate specific antigen: initial results in early prostate cancer. J Urol 2008; 179: 2187-191. doi: 10.1016/j.juro.2008.01.102

98. Ilie M, Hofman V, Long-Mira E, Selva E, Vignaud JM, Padovani B, et al "Sentinel" circulating tumor cells allow early diagnosis of lung cancer in patients with chronic obstructive pulmonary disease. Kalinichenko V V., ed. PLoS One 2014; 9: e111597. doi: 10.1371/journal.pone.0111597

99. Fiorelli A, Accardo M, Carelli E, Angioletti D, Santini M, Di Domenico M Circulating tumor cells in diagnosing lung cancer: clinical and morphologic analysis. Ann Thorac Surg 2015; 99: 1899-905. doi: 10.1016/j.athoracsur.2014.11.049

100. UICC International Union Against Cancer. TNM classification of malignant tumours. 7th edition. Sobin LH, Gospodarowicz MK, Wittekind C, editors. Chichester: Wiley-Blackwell; 2011.

101. Huang X, Gao P, Song Y, Sun J, Chen X, Zhao J, et al. Meta-analysis of the prognostic value of circulating tumor cells detected with the CellSearch System in colorectal cancer. BMC Cancer 2015; 15: 202. doi: 10.1186/ s12885-015-1218-9

102. Vlaeminck-Guillem V. When prostate cancer circulates in the bloodstream. Diagnostics. 2015; 5: 428-74. doi: 10.3390/diagnostics5040428

103. Krebs MG, Sloane R, Priest L, Lancashire L, Hou JM, Greystoke A, et al. Evaluation and prognostic significance of circulating tumor cells in patients with non-small-cell lung cancer. J Clin Oncol 2011; 29: 1556-63. doi: 10.1200/JCO.2010.28.7045

104. Hou J-M, Krebs MG, Lancashire L, Sloane R, Backen A, Swain RK, et al. Clinical significance and molecular characteristics of circulating tumor cells and circulating tumor microemboli in patients with small-cell lung cancer. $J$ Clin Oncol 2012; 30: 525-32. doi: 10.1200/JCO.2010.33.3716

105. Janni WJ, Rack B, Terstappen LWMM, Pierga JY, Taran FA, Fehm T, et al. Pooled analysis of the prognostic relevance of circulating tumor cells in primary breast cancer. Clin Cancer Res 2016; 22: 2583-93. doi: 10.1158/10780432.CCR-15-1603

106. Cohen SJ, Punt CJA, lannotti N, Saidman BH, Sabbath KD, Gabrail NY, et al. Relationship of circulating tumor cells to tumor response, progression-free survival, and overall survival in patients with metastatic colorectal cancer. $J$ Clin Oncol 2008; 26: 3213-21. doi: 10.1200/JCO.2007.15.8923

107. Bidard FC, Huguet F, Louvet $C$, Mineur L, Bouche $O$, Chibaudel $B$, et al. Circulating tumor cells in locally advanced pancreatic adenocarcinoma: the ancillary CirCe 07 study to the LAP 07 trial. Ann Oncol 2013; 24: 2057-61. doi: 10.1093/annonc/mdt176

108. Zhang L, Riethdorf S, Wu G, Wang T, Yang K, Peng G, et al. Meta-analysis of the prognostic value of circulating tumor cells in breast cancer. Clin Cancer Res 2012; 18: 5701-10. doi: 10.1158/1078-0432.CCR-12-1587

109. Grobe A, Blessmann M, Hanken H, Friedrich RE, Schön G, Wikner J, et al. Prognostic relevance of circulating tumor cells in blood and disseminated tumor cells in bone marrow of patients with squamous cell carcinoma of the oral cavity. Clin Cancer Res 2014; 20: 425-33. doi: 10.1158/1078-0432. CCR-13-1101

110. Tol J, Koopman M, Miller MC, Tibbe A, Cats A, Creemers GJM, et al. Circulating tumour cells early predict progression-free and overall survival in advanced colorectal cancer patients treated with chemotherapy and targeted agents. Ann Oncol 2010; 21: 1006-12. doi: 10.1093/annonc/mdp463 
111. Sastre J, Maestro ML, Gomez-Espana A, Rivera F, Valladares M, Massuti B, et al. Circulating tumor cell count is a prognostic factor in metastatic colorectal cancer patients receiving first-line chemotherapy plus bevacizumab: A Spanish Cooperative Group for the Treatment of Digestive Tumors Study. Oncologist 2012; 17: 947-55. doi: 10.1634/theoncologist.2012-0048

112. de Bono JS, Scher HI, Montgomery RB, Parker C, Miller MC, Tissing H, et al. Circulating tumor cells predict survival benefit from treatment in metastatic castration-resistant prostate cancer. Clin Cancer Res 2008; 14: 6302-9. doi: 10.1158/1078-0432.CCR-08-0872

113. Jansson S, Bendahl P-O, Larsson A-M, Aaltonen KE, Rydén L. Prognostic impact of circulating tumor cell apoptosis and clusters in serial blood samples from patients with metastatic breast cancer in a prospective observational cohort. BMC Cancer 2016; 16: 433. doi: 10.1186/s12885-016-2406-y

114. Lu CY, Uen YH, Tsai HL, Chuang SC, Hou MF, Wu DC, et al. Molecular detection of persistent postoperative circulating tumour cells in stages II and III colon cancer patients via multiple blood sampling: prognostic significance of detection for early relapse. Br J Cancer 2011; 104: 1178-84. doi: 10.1038/bjc.2011.40

115. Yamada T, Matsuda A, Koizumi M, Shinji S, Takahashi G, Iwai T, et al. Liquid biopsy for the management of patients with colorectal cancer. Digestion 2019; 99: 39-45. doi: 10.1159/000494411

116. Goodman CR, Seagle B-LL, Friedl TWP, Rack B, Lato K, Fink V, et al. Association of circulating tumor cell status with benefit of radiotherapy and survival in early-stage breast cancer. JAMA Oncol 2018; 4: e180163. doi: 10.1001/jamaoncol.2018.0163

117. Scher HI, Heller G, Molina A, Attard G, Danila DC, Jia X, et al. Circulating tumor cell biomarker panel as an individual-level surrogate for survival in metastatic castration-resistant prostate cancer. J Clin Oncol 2015; 33: 134855. doi: $10.1200 / J C O .2014 .55 .3487$

118. Bidard F-C, Peeters DJ, Fehm T, Nolé F, Gisbert-Criado R, Mavroudis D, et al. Clinical validity of circulating tumour cells in patients with metastatic breast cancer: a pooled analysis of individual patient data. Lancet Oncol 2014; 15: 406-14. doi: 10.1016/S1470-2045(14)70069-5

119. Yu M, Bardia A, Aceto N, Bersani F, Madden MW, Donaldson MC, et al. Ex vivo culture of circulating breast tumor cells for individualized testing of drug susceptibility. Science 2014; 345: 216-20. doi: 10.1126/science. 1253533

120. Gates JD, Benavides LC, Stojadinovic A, Mittendorf EA, Holmes JP, Carmichael MG, et al. Monitoring circulating tumor cells in cancer vaccine trials. Hum Vaccin 2008; 4: 389-92.

121. Lin M, Liang S-Z, Shi J, Niu LZ, Chen JB, Zhang MJ, et al. Circulating tumor cell as a biomarker for evaluating allogenic NK cell immunotherapy on stage IV non-small cell lung cancer. Immunol Lett 2017; 191: 10-5. doi: 10.1016/j.imlet.2017.09.004

122. Kalinsky K, Mayer JA, Xu X, Pham T, Wong KL, Villarin E, et al. Correlation of hormone receptor status between circulating tumor cells, primary tumor, and metastasis in breast cancer patients. Clin Transl Oncol 2015; 17: 53946. doi: 10.1007/s12094-015-1275-1

123. Lee JS, Magbanua MJM, Park JW. Circulating tumor cells in breast cancer: applications in personalized medicine. Breast Cancer Res Treat 2016; 160: 411-24. doi: 10.1007/s10549-016-4014-6

124. Tewes M, Aktas B, Welt A, Mueller S, Hauch S, Kimmig R, et al. Molecular profiling and predictive value of circulating tumor cells in patients with metastatic breast cancer: an option for monitoring response to breast cancer related therapies. Breast Cancer Res Treat 2009; 115: 581-90. doi: 10.1007/s10549-008-0143-x

125. Aktas B, Müller V, Tewes M, Zeitz J, Kasimir-Bauer S, Loehberg CR, et al. Comparison of estrogen and progesterone receptor status of circulating tumor cells and the primary tumor in metastatic breast cancer patients. Gynecol Oncol 2011; 122: 356-60. doi: 10.1016/j.ygyno.2011.04.039

126. Somlo G, Lau SK, Frankel P, Hsieh HB, Liu X, Yang L, et al. Multiple biomarker expression on circulating tumor cells in comparison to tumor tissues from primary and metastatic sites in patients with locally advanced/inflammatory, and stage IV breast cancer, using a novel detection technology. Breast Cancer Res Treat 2011; 128: 155-63. doi: 10.1007/s10549-011-1508-0

127. Paoletti C, Muñiz MC, Thomas DG, Griffith KA, Kidwell KM, Tokudome N, et al. Development of circulating tumor cell-endocrine therapy index in patients with hormone receptor-positive breast cancer. Clin Cancer Res 2015; 21: 2487-98, doi: 10.1158/1078-0432.CCR-14-1913
128. Jaeger BAS, Neugebauer J, Andergassen U, Melcher C, Schochter $F$ Mouarrawy D, et al. The HER2 phenotype of circulating tumor cells in HER2-positive early breast cancer: A translational research project of a prospective randomized phase III trial. PLoS One 2017; 12: e0173593. doi: 10.1371/journal.pone.0173593

129. Georgoulias V, Bozionelou V, Agelaki S, Perraki M, Apostolaki S, Kallergi G, et al. Trastuzumab decreases the incidence of clinical relapses in patients with early breast cancer presenting chemotherapy-resistant CK-19mRNApositive circulating tumor cells: results of a randomized phase II study. Ann Oncol 2012; 23: 1744-50. doi: 10.1093/annonc/mds020

130. Kulasinghe A, Kapeleris J, Kimberley R, Mattarollo SR, Thompson EW, Thiery JP, et al. The prognostic significance of circulating tumor cells in head and neck and non-small-cell lung cancer. Cancer Med 2018; 7: 5910-19. doi: $10.1002 /$ cam4.1832

131. Antonarakis ES, Lu C, Luber B, Wang $H$, Chen $Y$, Nakazawa $M$, et al. Androgen receptor splice variant 7 and efficacy of taxane chemotherapy in patients with metastatic castration-resistant prostate cancer. JAMA Oncol 2015; 1: 582. doi: 10.1001/jamaoncol.2015.1341

132. Payne RE, Yagüe E, Slade MJ, Apostolopoulos C, Jiao LR, Ward B, et al Measurements of EGFR expression on circulating tumor cells are reproducible over time in metastatic breast cancer patients. Pharmacogenomics 2009; 10: 51-7. doi: 10.2217/14622416.10.1.51

133. Nadal R, Ortega FG, Salido M, Lorente JA, Rodríguez-Rivera M, DelgadoRodríguez M, et al. CD133 expression in circulating tumor cells from breast cancer patients: potential role in resistance to chemotherapy. Int J Cancer 2013; 133: 2398-407. doi: 10.1002/ijc.28263

134. Baccelli I, Schneeweiss A, Riethdorf S, Stenzinger A, Schillert A, Vogel V, et al. Identification of a population of blood circulating tumor cells from breast cancer patients that initiates metastasis in a xenograft assay. Nat Biotechnol 2013; 31: 539-44. doi: 10.1038/nbt.2576

135. Tellez-Gabriel M, Cochonneau D, Cadé M, Jubellin C, Heymann MF, Heymann D. Circulating tumor cell-derived pre-clinical models for personalized medicine. Cancers (Basel) 2018; 11.1: 19. doi: 10.3390/cancers11010019

136. Whittle JR, Lewis MT, Lindeman GJ, Visvader JE. Patient-derived xenograft models of breast cancer and their predictive power. Breast Cancer Res 2015; 17: 17. doi: 10.1186/s13058-015-0523-1

137. Lallo A, Gulati S, Schenk MW, Khandelwal G, Berglund UW, Pateras IS, et al. Ex vivo culture of cells derived from circulating tumour cell xenograft to support small cell lung cancer research and experimental therapeutics. $\mathrm{Br}$ J Pharmacol 2018; 176.3: 436-50. doi: 10.1111/bph.14542

138. Pereira-Veiga T, Abreu M, Robledo D, Matias-Guiu X, Santacana M, Sánchez $L$, et al. CTCs-derived xenograft development in a triple negative breast cancer case. Int J Cancer 2019; 144: 2254-65. doi: 10.1002/ijc.32001

139. Williams ES, Rodriquez-Bravo V, Chippada-Venkata U, Iglesia-Vicente JDI, Gong Y, Galsky M, et al. Generation of prostate cancer patient derived xenograft models from circulating tumor cells. J Vis Exp 2015; 104: e53182. doi: $10.3791 / 53182$

140. Pierga JY, Hajage D, Bachelot T, Delaloge S, Brain E, Campone M, et al. High independent prognostic and predictive value of circulating tumor cells compared with serum tumor markers in a large prospective trial in first-line chemotherapy for metastatic breast cancer patients. Ann Oncol 2012; 23: 618-24. doi: 10.1093/annonc/mdr263

141. Cristofanilli M, Hayes DF, Budd GT, Ellis MJ, Stopeck A, Reuben JM, et al. Circulating tumor cells: a novel prognostic factor for newly diagnosed metastatic breast cancer. J Clin Oncol 2005; 23: 1420-30. doi: 10.1200/ JCO.2005.08.140

142. Dawood S, Broglio K, Valero V, Reuben J, Handy B, Islam R, et al. Circulating tumor cells in metastatic breast cancer. Cancer 2008; 113: 2422-30. doi: 10.1002/cncr.23852

143. Hayes DF, Cristofanilli M, Budd GT, Ellis MJ, Stopeck A, Miller MC, et al. Circulating tumor cells at each follow-up time point during therapy of metastatic breast cancer patients predict progression-free and overall survival. Clin Cancer Res 2006; 12: 4218-24. doi: 10.1158/1078-0432.CCR-05-2821

144. Nole F, Munzone E, Zorzino L, Minchella I, Salvatici M, Botteri E, et al. Variation of circulating tumor cell levels during treatment of metastatic breast cancer: prognostic and therapeutic implications. Ann Oncol 2008; 19: 891-7. doi: 10.1093/annonc/mdm558 
145. Paoletti C, Li Y, Muniz MC, Kidwell KM, Aung K, Thomas DG, et al. Significance of circulating tumor cells in metastatic triple-negative breast cancer patients within a randomized, phase II trial: TBCRC 019. Clin Cancer Res 2015; 21: 2771-9. doi: 10.1158/1078-0432.CCR-14-2781

146. Yan WT, Cui X, Chen Q, Li YF, Cui YH, Wang, Y, et al. Circulating tumor cell status monitors the treatment responses in breast cancer patients: a metaanalysis. Sci Rep 2017; 7: 43464. doi: 10.1038/srep43464

147. Giuliano M, Giordano A, Jackson S, Hess KR, De Giorgi U, Mego M, et al. Circulating tumor cells as prognostic and predictive markers in metastatic breast cancer patients receiving first-line systemic treatment. Breast Cancer Res 2011; 13: R67. doi: 10.1186/bcr2907

148. Budd GT, Cristofanilli M, Ellis MJ, Stopeck A, Borden E, Miller MC, et al. Circulating tumor cells versus imaging--predicting overall survival in metastatic breast cancer. Clin Cancer Res 2006; 12: 6403-9. doi: 10.1158/10780432.CCR-05-1769

149. Mego M, De Giorgi U, Dawood S, Wang X, Valero V, Andreopoulou E, et al. Characterization of metastatic breast cancer patients with nondetectable circulating tumor cells. Int J Cancer 2011; 129: 417-23. doi: 10.1002/ ijc. 25690

150. Smerage JB, Barlow WE, Hortobagyi GN, Winer EP, Leyland-Jones B, Srkalovic $\mathrm{G}$, et al. Circulating tumor cells and response to chemotherapy in metastatic breast cancer: SWOG S0500. J Clin Oncol 2014; 32: 3483-89. doi: 10.1200/JCO.2014.56.2561

151. Thiery JP, Lim CT. Tumor Dissemination: An EMT Affair. Cancer Cell 2013; 23: 272-3. doi: 10.1016/j.ccr.2013.03.004

152. Mooney SM, Talebian V, Jolly MK, Jia D, Gromala M, Levine $H$, et al. The GRHL2/ZEB feedback loop-a key axis in the regulation of EMT in breast cancer. J Cell Biochem 2017; 118: 2559-70. doi: 10.1002/jcb.25974

153. Pattabiraman DR, Weinberg RA. Targeting the epithelial-to-mesenchymal transition: the case for differentiation-based therapy. Cold Spring Harb Symp Quant Biol 2016; 81: 11-9. doi: 10.1101/sqb.2016.81.030957

154. Giordano A, Giuliano M, De Laurentiis M, Arpino G, Jackson S, Handy BC, et al. Circulating tumor cells in immunohistochemical subtypes of metastatic breast cancer: lack of prediction in HER2-positive disease treated with targeted therapy. Ann Oncol 2012; 23: 1144-50. doi: 10.1093/annonc/ mdr434

155. Lu Y, Wang P, Wang X, Peng J, Zhu Y, Shen N. The significant prognostic value of circulating tumor cells in triple-negative breast cancer: a metaanalysis. Oncotarget 2016; 7: 37361-9. doi: 10.18632/oncotarget.8156

156. Riethdorf S, O'Flaherty L, Hille C, Pantel K. Clinical applications of the CellSearch platform in cancer patients. Adv Drug Deliv Rev 2018; 125: 10221. doi: 10.1016/j.addr.2018.01.011

157. Rack B, Schindlbeck C, Jückstock J, Andergassen U, Hepp P, Zwingers T, et al . Circulating tumor cells predict survival in early average-to-high risk breast cancer patients. JNCI J Nat/ Cancer Inst 2014; 106.5. doi: 10.1093/jnci/ dju066

158. Sandri MT, Zorzino L, Cassatella MC, Bassi F, Luini A, Casadio C, et al. Changes in circulating tumor cell detection in patients with localized breas cancer before and after surgery. Ann Surg Oncol 2010; 17: 1539-45. doi: 10.1245/s10434-010-0918-2

159. Krishnamurthy S, Cristofanilli M, Singh B, Anfossi S, Khoury J, Hess K, et al. Detection of minimal residual disease in blood and bone marrow in early stage breast cancer. Cancer 2010; 116: 3330-7. doi: 10.1002/cncr.25145

160. Lucci A, Hall CS, Lodhi AK, Bhattacharyya A, Anderson AE, Xiao L, et al. Circulating tumour cells in non-metastatic breast cancer: a prospective study. Lancet Oncol 2012; 13: 688-95. doi: 10.1016/S1470-2045(12)702097

161. Hall CS, Karhade MG, Bowman Bauldry JB, Valad LM, Kuerer HM, DeSnyder $\mathrm{SM}$, et al. Prognostic value of circulating tumor cells identified before surgical resection in nonmetastatic breast cancer patients. J Am Coll Surg 2016; 223: 20-9. doi: 10.1016/j.jamcollsurg.2016.02.021

162. Hartkopf AD, Wallwiener M, Hahn M, Fehm TN, Brucker SY, Taran FA Simultaneous detection of disseminated and circulating tumor cells in primary breast cancer patients. Cancer Res Treat 2016; 48: 115-24. doi: $10.4143 /$ crt.2014.287

163. Riethdorf S, Müller V, Loibl S, Nekljudova V, Weber K, Huober J, et al. Prognostic impact of circulating tumor cells for breast cancer patients treated in the neoadjuvant "Geparquattro« trial. Clin Cancer Res 2017; 23: 5384-93. doi: 10.1158/1078-0432.CCR-17-0255
164. Riethdorf S, Muller V, Zhang L, Rau T, Loibl S, Komor M, et al. Detection and HER2 expression of circulating tumor cells: prospective monitoring in breast cancer patients treated in the neoadjuvant GeparQuattro trial. Clin Cancer Res 2010; 16: 2634-45. doi: 10.1158/1078-0432.CCR-09-2042

165. Pierga JY, Bidard FC, Mathiot C, Brain E, Delaloge S, Giachetti S, et al Circulating tumor cell detection predicts early metastatic relapse after neoadjuvant chemotherapy in large operable and locally advanced breast cancer in a phase II randomized trial. Clin Cancer Res 2008; 14: 7004-10. doi: 10.1158/1078-0432.CCR-08-0030

166. Scher HI, Jia X, de Bono JS, Fleisher M, Pienta KJ, Raghavan D, et al. Circulating tumour cells as prognostic markers in progressive, castrationresistant prostate cancer: a reanalysis of IMMC38 trial data. Lancet Oncol 2009; 10: 233-9. doi: 10.1016/S1470-2045(08)70340-1

167. Goodman OB, Fink LM, Symanowski JT, Wong B, Grobaski B, Pomerantz D, et al. Circulating tumor cells in patients with castration-resistant prostate cancer baseline values and correlation with prognostic factors. Cance Epidemiol Biomarkers Prev 2009; 18: 1904-13. doi: 10.1158/1055-9965. EPI-08-1173

168. Okegawa T, Itaya N, Hara H, Tambo M, Nutahara K. Circulating tumor cells as a biomarker predictive of sensitivity to docetaxel chemotherapy in patients with castration-resistant prostate cancer. Anticancer Res 2014; 34 : 6705-10.

169. Vogelzang NJ, Fizazi K, Burke JM, De Wit R, Bellmunt J, Hutson TE, et al. Circulating tumor cells in a phase 3 study of docetaxel and prednisone with or without lenalidomide in metastatic castration-resistant prostate cancer. Eur Urol 2017; 71: 168-71. doi: 10.1016/j.eururo.2016.07.051

170. Goldkorn A, Ely B, Quinn DI, Tangen CM, Fink LM, Xu T, et al. Circulating tumor cell counts are prognostic of overall survival in SWOG S0421: a phase III trial of docetaxel with or without atrasentan for metastatic castrationresistant prostate cancer. J Clin Oncol 2014; 32: 1136-42. doi: 10.1200/ JCO.2013.51.7417

171. Scher HI, Morris MJ, Stadler WM, Higano C, Basch E, Fizazi K, et al. Trial design and objectives for castration-resistant prostate cancer: updated recommendations from the Prostate Cancer Clinical Trials Working Group 3. J Clin Oncol 2016; 34: 1402-18. doi: 10.1200/JCO.2015.64.2702

172. Danila DC, Heller G, Gignac GA, Gonzalez-Espinoza R, Anand A, Tanaka $E$, et al. Circulating tumor cell number and prognosis in progressive castration-resistant prostate cancer. Clin Cancer Res 2007; 13: 7053-8. doi: 10.1158/1078-0432.CCR-07-1506

173. Thalgott M, Rack B, Horn T, Heck MM, Eiber M, Kübler H, et al. Detection of circulating tumor cells in locally advanced high-risk prostate cancer during neoadjuvant chemotherapy and radical prostatectomy. Anticancer Res 2015; 35: 5679-85.

174. Meyer CP, Pantel K, Tennstedt P, Stroelin P, Schlomm T, Heinzer H, et al. Limited prognostic value of preoperative circulating tumor cells for early biochemical recurrence in patients with localized prostate cancer. Urol Oncol Semin Orig Investig 2016; 34: 235.e11-235.e16. doi: 10.1016/j. urolonc.2015.12.003

175. Loh J, Jovanovic L, Lehman M, Capp A, Pryor D, Harris M, et al. Circulating tumor cell detection in high-risk non-metastatic prostate cancer. J Cancer Res Clin Oncol 2014; 140: 2157-62. doi: 10.1007/s00432-014-1775-3

176. Okegawa T, Nutahara K, Higashihara E. Immunomagnetic quantification of circulating tumor cells as a prognostic factor of androgen deprivation responsiveness in patients with hormone naive metastatic prostate cancer J Urol 2008; 180: 1342-7. doi: 10.1016/j.juro.2008.06.021

177. Goodman OB, Symanowski JT, Loudyi A, Fink LM, Ward DC, Vogelzang NJ. Circulating tumor cells as a predictive biomarker in patients with hormone-sensitive prostate cancer. Clin Genitourin Cancer 2011; 9: 31-8. doi: 10.1016/j.clgc.2011.04.001

178. Resel Folkersma L, San José Manso L, Galante Romo I, Moreno Sierra J, Olivier Gómez C. Prognostic significance of circulating tumor cell count in patients with metastatic hormone-sensitive prostate cancer. Urology 2012; 80: 1328-32. doi: 10.1016/j.urology.2012.09.001

179. Rink M, Chun FKH, Minner S, Friedrich M, Mauermann O, Heinzer H, et al. Detection of circulating tumour cells in peripheral blood of patients with advanced non-metastatic bladder cancer. BJU Int 2011; 107: 1668-75. doi: 10.1111/j.1464-410X.2010.09562.x 
180. Rink M, Chun FK, Dahlem R, Soave A, Minner S, Hansen J, et al. Prognostic role and HER2 expression of circulating tumor cells in peripheral blood of patients prior to radical cystectomy: a prospective study. Eur Urol 2012; 61: 810-7. doi: 10.1016/j.eururo.2012.01.017

181. Soave A, Riethdorf S, Dahlem R, Minner S, Weisbach L, Engel O, et al. Detection and oncological effect of circulating tumour cells in patients with variant urothelial carcinoma histology treated with radical cystectomy. BJU Int 2017; 119: 854-61. doi: 10.1111/bju.13782

182. Nastały P, Ruf C, Becker P, Bednarz-Knoll N, Stoupiec M, Kavsur R, et al. Circulating tumor cells in patients with testicular germ cell tumors. Clin Cancer Res 2014; 20: 3830-41. doi: 10.1158/1078-0432.CCR-13-2819

183. Gorin MA, Verdone JE, van der Toom E, Bivalacqua TJ, Allaf ME, Pienta KJ. Circulating tumour cells as biomarkers of prostate, bladder and kidney cancer. Nat Rev Urol 2017; 14: 90-7. doi: 10.1038/nrurol.2016.224

184. Gradilone A, lacovelli R, Cortesi E, Raimondi C, Gianni W, Nicolazzo C, et al. Circulating tumor cells and "suspicious objects" evaluated through CellSearch ${ }^{\circledast}$ in metastatic renal cell carcinoma. Anticancer Res 2011; 31: 4219-21.

185. van Dalum G, Stam GJ, Scholten LF, Mastboom WJ, Vermes I, Tibbe AG, et al. Importance of circulating tumor cells in newly diagnosed colorectal cancer. Int J Oncol 2015; 46: 1361-8. doi: 10.3892/ijo.2015.2824

186. Bissolati M, Sandri MT, Burtulo G, Zorzino L, Balzano G, Braga M. Portal vein-circulating tumor cells predict liver metastases in patients with resectable pancreatic cancer. Tumor Biol 2015; 36: 991-6. doi: 10.1007/s13277014-2716-0

187. Khoja L, Backen A, Sloane R, Menasce L, Ryder D, Krebs M, et al. A pilot study to explore circulating tumour cells in pancreatic cancer as a novel biomarker. Br J Cancer 2012; 106: 508-16. doi: 10.1038/bjc.2011.545

188. Yang JD, Campion MB, Liu MC, Chaiteerakij R, Giama NH, Mohammed $\mathrm{HA}$, et al. Circulating tumor cells are associated with poor overall survival in patients with cholangiocarcinoma. Hepatology 2016; 63: 148-58. doi: 10.1002/hep. 27944

189. Naito T, Tanaka F, Ono A, Yoneda K, Takahashi T, Murakami H, et al. Prognostic impact of circulating tumor cells in patients with small cell lung cancer. J Thorac Oncol 2012; 7: 512-9. doi: 10.1097/JTO.0b013e31823f125d

190. Hiltermann TJN, Pore MM, van den Berg A, Timens W, Boezen HM, Liesker JJW, et al. Circulating tumor cells in small-cell lung cancer: a predictive and prognostic factor. Ann Oncol 2012; 23: 2937-42. doi: 10.1093/annonc/ mds138

191. Komine K, Inoue M, Otsuka K, Fukuda K, Nanjo H, Shibata H. Utility of measuring circulating tumor cell counts to assess the efficacy of treatment for carcinomas of unknown primary origin. Anticancer Res 2014; 34: 3165-8. 